\title{
Failing Faith: Adjudicatory Procedure in Decline
}

\author{
Judith Resnik $\dagger$
}

We are approaching the fiftieth anniversary of the enactment of the Federal Rules of Civil Procedure. ${ }^{1}$ Reconsideration of the Rules is appropriate for several reasons, not the least of which is to pause in admiration of a formidable accomplishment. For members of my generation, who grew up in law with rules that assume the desirability of nontechnical approaches to procedure, it is easy to ignore the tremendous contribution that the Rules have made to our thinking. Hence praise, accolades, and affection are due the group which created the Federal Rules of Civil Procedure.

But this is not simply a time for rejoicing at a prior generation's achievements. Many in the legal profession now criticize aspects of the Rules and demand revision. ${ }^{2}$ Critics claim that the

$\dagger$ Professor of Law, University of Southern Califormia Law Center. This essay grew out of my comments on Don Elliott's paper at the National Conference on Litigation Management, co-sponsored by Yale Law School, the American Bar Association Litigation Section, and the Center for Public Resources. This paper was presented to workshops at the University of Southern California Law Center and at the University of California Law School at Los Angeles. My thanks to the participants at these meetings, and to Steve Burbank, Don Elliott, Owen Fiss, Dan Freed, Bill Genego, Carrie Menkel-Meadow, and Steve Suhrin, for helpful discussions of the problems raised here, to Katie Waitman, for editorial and proofreading work, to Julie Huffman and Jackie Chooljian, for research assistance, and to Deborah Malamud, for thoughtful law review editing. Special thanks are owed to Bob Bone, Steve Yeazell, and Denny Curtis for the many hours of conversations that influenced this paper.

1 The Federal Rules of Civil Procedure ("the Rules") were enacted pursuant to the Rules Enabling Act, Pub. L. No. 73-415, 48 Stat. 1064 (1934) (codified as amended at 28 U.S.C. $\$ 2072$ (1982)). In 1935, the Supreme Court appointed an Advisory Committee to draft the Rules. Order Appointing Committee to Draft Unified Systein of Equity and Law Rules, 295 U.S. 774 (1935) [hereinafter cited as Appointment of Committee]. With minor modifications, the Court promulgated the Rules as drafted by the Committee. The Rules were transinitted by the Court to the Attorney General on December 20, '1937, and by the Attorney General to Congress on January 3, 1938. They became effective on September 16, 1938. See Rules of Civil Procedure, 308 U.S. 645 (1938).

For a comprehensive history of the drafting process, see Burbank, The Rules Enabling Act of 1934, 130 U. PA. L. REv. 1015 (1982). For descriptions of the drafting process, see Chandler, Some Major Advances in the Federal Judicial System, 1922-47, 31 F.R.D. 307, 493-98 (1963).

2 See, e.g., Order Amending the Federal Rules of Civil Procedure, 446 U.S. 997, 1000 (1980) (Powell, J., joined by Stewart and Relıquist, JJ., dissenting) (the amendinents fail 
federal courts are in "crisis" and argue that some of the current problems are properly charged to decisions made fifty years ago, including reliance upon one trans-substantive set of rules for all kinds of cases, ${ }^{3}$ upon minimal pleading requirements, ${ }^{4}$ and upon discovery as a technique for issue identification. ${ }^{5}$ Many of the critics hope to limit what they perceive to be an avalanche of hitigation and an unrestrained exploitation by litigants and attorneys of the procedural opportunities made available by the Rules.

One need neither endorse all of these criticisms nor accept the empirical validity of the descriptions upon which the criticisms are based $^{6}$ to join in a call for review of the Federal Rules. The Rules

to curb discovery abuse, and "Congress' acceptance of these tinkering changes will delay for years the adoption of genuinely effective reforms"); Burger, Introduction to Reducing the Costs of Civil Litigation, 37 RuTGERs L. REv. 217, $217-18$ (1985); Discovery Abuse: Causes, Effects, and Reform, 3 REv. of LITIGation 1 (1982).

3 See Cover, For James Wm. Moore: Some Reflections on a Reading of the Rules, 84 YALE L.J. 718 (1975).

4 Some retreat from the liberality of pleading may already have occurred. See Associated Gen. Contractors v. California State Council of Carpenters, 459 U.S. 519 (1983) (upholding district court's dismissal of antitrust claim on the pleadimgs); see also Local Rule Re Fed. R. Civ. P. 16b (D.S.C.), in 2 Federal Local Court Rules for Civil and Admiralty Prockedings (Callaghan 1985) [hereinafter cited as Local CouRT Rules] (court imterrogatories to the parties to obtain specificity about alleged misconduct and defenses). But see Associated General Contractors, 459 U.S. at 552 (Marshall, J., dissenting) ("Any concern the Court may have that the plaintiffs cannot prove their case does not justify throwing tbem out of court solely on the basis of the pleadings . . . . Dismissal for failure to state a claim is too crude a procedural device to be used to vindicate" the court's stated interest in narrowing the scope of complex trials.); McLain v. Real Estate Bd., 444 U.S. 232, 246 (1980) (stating that liberal pleading requirements "appl[y] with no less force" to antitrust claims). See generally Marcus, The Revival of Fact Pleading under the Federal Rules of Civil Procedure, 86 Colum. L. Rev. 201 (1986).

- See Brazil, The Adversary Character of Civil Discovery: A Critique and Proposals for Change, 31 Vand. L. REv. 1295, 1348-61 (1978) (advocating reforms to shift attorneys' loyalties from client to court during the discovery process).

- Federal courts might be described as functioning quite well. The median time from filing to disposition in civil cases in 1984 was seven months; in cases tried, the median time was 19 months. Administrative Orfice of the United States Courts, Annual Report or THE Director 286. (1984) [hereinafter cited as 1984 ADministrative Ofrice Report]. Further, the rising number of filings could be interpreted as a sign of satisfaction with the courts. Moreover, despite the current popularity of claiming that both the federal and state courts are beset by backlogs, some commentators have expressed skepticism about at least the novelty of the problem. See M. Semvin \& P. Ebengr, Managing the Unmanageable at vi (1984) ("Our time-to-trial data indicate that civil delay is neither a recent phenomenon nor a temporary one."); Friedman, The Six Million Dollar Man: Litigation and Rights Consciousness in Modern America, 39 MD. L. REv. 661, 663 (1980) (questioning whether real litigation rates have risen); Galanter, Reading the Landscape of Disputes: What We Know and Don't Know (and Think We Know) about Our Allegedly Contentious and Litigious Society, 31 UCLA L. REv. 4 (1983) (same). For an earher cry of distress, which in turn created an atmosphere hospitable to reform, see Pound, The Causes of Popular Dissatisfaction with the Administration of Justice, 29 REPORT OF THE A.B.A. 395 (1906), reprinted in 
were intended as an ample umbrella for federal litigation, but the Rules are silent about many issues of great saliency today. The simplest example is settlement, the focus currently of a good deal of attention. ' At a practical level, the Rules do not inform litigators about what pieces of paper must be filed to obtain entry of a consent judgment. ${ }^{8}$ At a more theoretical level, the Rules fail to address what role, if any, judges should play in shaping settlements and how judges should assess the adequacy of the compromises reached. ${ }^{9}$ Settlement is not the only lacuna in the Rules. Why do the Rules fail to delineate the appropriate pace for litigation? Why didn't the drafters, who required attorneys to cooperate in discovery, provide resolutions for the tensions between this requirement and the traditional adversarial stance of lawyers? ${ }^{10}$

20 J. Am. Judicature Soc'y 178 (1937); see also Wigmore, Roscoe Pound's St. Paul Address of 1906: The Spark that Kindled the White Flame of Progress, 20 J. AM. JudicatuRE Soc'y 176 (1937).

7 See Marek v. Chesny, 105 S. Ct. 3012 (1985) (addressing question of imposing sanctions for failure to settle); see also Fiss, Against Settlement, 93 Yale L.J. 1073 (1984); McThenia \& Shaffer, For Reconciliation, 94 YALE L.J. 1660 (1985) (critique of Fiss's position); Fiss, Out of Eden, 94 YALE L.J. 1669 (1985) (response to McThenia \& Shaffer).

8 Rules 54 ("Judgments; Costs") and 58 ("Entry of Judgment") of the Federal Rules provide for judgments, but neither rule specifically discusses the procedures for submitting proposed consent judgments. Consent judgments are typically used in actions in which the hitigants foresee enforcement difficulties. In many cases, litigants simply stipulate to the dismissal of the lawsint. See FED. R. Crv. P. 41.

- Rule 23(e) does provide that a class action cannot be withdrawn or compromised without court approval, but no standard is provided for when approval should be granted. See infra notes 254-62 and accompanying text. Current case law has engrafted a series of tests for the "fairness" or "adequacy" of class action settlements. See, e.g., Armstrong v. Board of School Directors, 616 F.2d 305, 314 (7th Cir. 1980); Note, Voluntarily Unlocking the Schoolhouse Door: The Use of Class Action Consent Decrees in School Desegregation, 59 WASH. L.Q. 1305, 1320-30 (1982); cf. 15 U.S.C. $\$ \S 16(b)$-(h) (1982) (antitrust actions initiated by the federal government cannot be compromised without public notice and a determination that the settlement is in "the public interest"). For a case study of the role of the judge in settling a class action, see Schuck, The Role of the Judge in Settling Complex Cases: The Agent Orange Example, 53 U. CHI. L. REv. 337 (1986).

The 1938 rule drafters were aware that cases frequently settled. See, e.g., C. CLARK \& H. Shulman, A Study of Law Administration in Connecticut 20-27 (1937) (examining modes of disposition in civil cases and describing cases terminated by "stipulation," in which the parties compromised). Further, the 1938 version of the class action rule also stated that "[a] class action shall not be dismissed or compromised without the approval of the court." FED. R. Crv. P. 23(c) (1938) (codified as amended at FED. R. Crv. P. 23(e)). One commentator noted at the time that the subsection "clearly contemplat[ed] that the court shall exercise rather complete control over the dismissal or compromise of class actions." 2 PALMER EDmunds, Federal Rules of Civil Procedure 972 (1938). However, the concerns appear to have been about the propriety of binding absentees, rather than about the quality of the outcome reached by settlement. See Moore \& Cohn, Federal Class Actions, 32 ILL. L. Rev. 307, 321-25 (1937).

${ }^{10}$ Edson Sunderland, a member of the Advisory Committee, praised the Rules' pretrial process (his area of special interest) as substituting "an open, business-like and efficient 
It is not only the silence of the Rules about specific issues that requires attention; the changing rhetoric about the Rules also merits comment. During the past fifty years, discussions about the function of the Federal Rules have undergone a substantial transformation. We have moved from arguments about the need to foster judicial decisions "on the merits" by simplifying procedure ${ }^{11}$ to conversations about the desirability of limiting the use of courts in general and of the federal courts in particular. ${ }^{12}$ Today's programs feature "alternative dispute resolution" techniques, advertised as preferable to trials, judges, and hitigation. ${ }^{13}$ From the left, court processes are criticized as empty and formalistic, a facade of procedural regularity in an unfair world. ${ }^{14}$ From the right, judges are depicted as "running amok," lured (in part) by procedural license into decisions beyond their ken. ${ }^{15}$ Whether the cry is for more therapeutic methods of dispute resolution" ${ }^{16}$ or for "managerial judges" to control wayward attorneys and to stabilize a malfunctioning process, ${ }^{17}$ the requests are often the same: limit opportuni-

presentation of real issues for the traditional strategy of concealment and disguise." Sunderland, Growth of Pre-Trial Procedure, 44 CoM. L.J. 406, 410 (1939). Sunderland appears to have been interested in increased court control of the pretrial process. See, e.g., Sunderland, The Theory and Practice of Pre-Trial Procedure, 36 Mrch. L. Rev. 215, 218-19 (1937) ("[T]here is no reason why the court should not itself take a hand in the investigation, supplementing the pleadings and the discovery which the parties have obtained, by direct interrogation of counsel or parties in the presence of each other.").

${ }^{11}$ E.g., Moore, The New Federal Rules of Civil Procedure, 6 I.C.C. Prac. J. 41, 42 (1939) ("The Federal rules . . . epitomize the new objective of all procedure . . . that litigation ouglit to be settled on the merits and not upon some procedural ground.").

${ }^{12}$ See generally Richard A. Posner, The Federal Courts: Crisis and Reform (1985).

13 The Center for Public Resources provided each of the conferees at the National Conference on Litigation Management, held in New Haven, Connecticut in October 1985, with a compendium of information about alternatives to litigation. Center for Public Resources, An ADR Manual for Judges (Working Draft Oct. 1985) (on file with The University of Chicago Law Review) [heremafter cited as ADR Manual]. See also the materials provided by the sponsors of the National Symposium on Civil Justice Issues, Apr. 30-May 1, 1986 New York, New York (on file with The University of Chicago Law Review).

14 See, e.g., The Politics of Informal Justice: Comparative Studirs (R. Abel ed. 1982); Abel, Informalism: A Tactical Equivalent to Law, 19 Clearinghouse Rev. 375 (1985); Simon, Legal Informality and Redistributive Politics, 19 Clearinghouse Rev. 384 (1985); Jozl Handere, The Conditions of Discretion: Autonomy, Community, BureauCRACY (forthcoming 1986).

${ }^{18}$ Horowitz, Decreeing Organizational Change: Judicial Supervision of Public Institutions, 1983 Duke L.J. 1265.

16 See, e.g., McThenia \& Shaffer, supra note 7, at 1664 (settlement is concerned with healing the "anger of broken relationships"); Riskin, Mediation and Lawyers, 43 OHI ST. L.J. 29, 57 (1982) (mediation "fosters interaction among people and empowers them to control their own lives").

${ }^{17}$ See generally Peckham, The Federal Judge as a Case Manager: The New Role in Guiding a Case from Filing to Disposition, 69 CAIIF. L. REv. 770 (1981) (praising managerial 
ties for adjudication by judges and for trial by jury and offer different mechanisms for the disposition of disputes.

The Federal Rules of Civil Procedure are, of course, only one piece of the story. Many other events, within and without courthouses, have brought forth contemporary criticism of the judicial process. ${ }^{18}$ This essay is primarily concerned, however, with the Rules and the litigation context in which they have operated over the past fifty years. This is a preliminary effort ${ }^{19}$ to make some sense of why the drafters did what they did, to consider how the Rules in turn helped to create the environment that has given rise to the contemporary critique, and to outline the tasks and choices facing us today.

\section{A VIEW FROM THE THIRTIES AND FORTIES}

A part of this enterprise is the attempt to understand the world of cases and problems to which the 1938 Federal Rules of Civil Procedure were thought to be an ameliorative response. Of course, I do not (and could not) claim to know the thoughts of the diverse individuals (such as Charles Clark, William Mitchell, Edmund Morgan, George Pepper, Edson Sunderland, and Edgar Tolman) who comprised the Advisory Committee that prepared drafts of the Rules for the Supreme Court, ${ }^{20}$ nor do I assume that they

judging); Resnik, Managerial Judges, 96 HARv. L. REv. 374 (1982) (critiquing managerial judging).

18 For discussion of the "courts in context," see Sarat, The Litigation Explosion, Access to Justice, and Court Reform: Examining the Critical Assumptions, 37 RUTGERs L. REv. 319, 331 (1985).

10 This essay is related to a larger project, and the limits of this portion of the enterprise should be set forth at the outset. First, this article does not purport to be a "history" of the Rules. Rather, it is an effort to understand what might have animated the drafters, in order to shed better light on what animates those of us who think about these problems today. Second, as Professor Burbank's work on the federal rules details, an extensive, unpublished, documentary record concerning the drafting process is available. See Burbank, supra note 1 , at 1132 n.529. I have not rehied upon those materials.

${ }^{20}$ The Supreme Court appointed William Mitchell (Chair), Charles Clark (Reporter), Scott Loftin, George Wickersham, Wilbur Cherry, Armistead Dobie, Robert Dodge, George Donworth, Joseph Gamble, Monte Lemann, Edmund Morgan, Warren Olney, Edson Sunderland, and Edgar Tolman to the Advisory Committee. Appointment of Committee, supra note 1. Wickersham died and was replaced by George Pepper. Order, 297 U.S. 731 (1936). J. William Moore, an instructor and eventually a professor at Yale Law School, was mitially a research associate to Charles Clark. Althougl Moore did not become a member of the Advisory Committee until 1953, Order, 345 U.S. 932 (1953), he was considered an expert on the Rules long before his appoimtment. See Manton, Preface to J. Moore \& J. Friedman, FedERAL Practice at v (1938) ("the first text published on these rules"); Dobie, Book Raview, 25 VA. L. REv. 749 (1939) (reviewing Moore's treatise).

In 1942, the Court designated the surviving members of the original Advisory Commit- 
shared a collective "intent." Indeed, from the history of the drafting debates (and from wbat one knows of life in general), it must be supposed that there was a fair amount of disagreement within the group. ${ }^{22}$ Furtler, not all the voices of those on the Advisory Committee can be heard distinctly today. The academics on the Committee lave left the richest record; the practicing lawyers' views are less accessible. ${ }^{23}$

Nevertheless, the task of reviewing the public record of the debate which surrounded the ruledrafting efforts and comparing that debate with contemporary rhetoric is intriguing. What role did the drafters claim that their rules would play? These were, after all, the pillars of the legal community, individuals who represented powerful interests in the society, ${ }^{24}$ making clooices quite at

tee as a standing Advisory Committee. Order Continuing the Advisory Committee, 314 U.S. 720 (1942). The standing committee was discharged in 1956. Order Discharging the Advisory Committee, 352 U.S. 803 (1956). In 1958, Congress gave the function of advising the Court on the need for changes in the Rules to the Judicial Conference of the United States. Pub. L. No. 85-513, 72 Stat. 356 (1958) (codified at 28 U.S.C. $\$ 331$ (1982)).

21 The difficulties of divining "intent" have been well chronicled by those who write about constitutional interpretation. See, e.g., Ronald Dworkin, TAkIng Rights SeriousLy 132-37 (1977); Simon, The Authority of the Framers of the Constitution: Can Originalist Interpretation be Justified?, 73 CALIR. L. REv. 1482 (1985); Stone, Introduction: Interpreting the Symposium, 58 S. CAL. L. REv. 1 (1985).

${ }^{22}$ See, e.g., Smith, Judge Charles E. Clark and the Federal Rules of Civil Procedure, 85 Yale L.J. 914, 953 (1976) (detailing points at which Clark and the other drafters disagreed, and arguing that Clark, once he became a judge, tended to "adhere to his own views rather than to the Rules"). For commentary indicating the drafters' disagreement on the drafts of the Federal Rules, see generally P. EDMunds, supra note 9 (annotations include commentary by members of the Advisory Committee). The drafting process is described in Chandler, supra note 1.

${ }^{23}$ As these footnotes will suggest, Professors Clark, Sunderland, and Moore wrote extensively about the Rules.

24 The Advisory Committee was composed of leading lawyers (active in the bar and in politics) and of law professors. Chairman Mitehell, a member of a Minnesota corporate firm of Mitchell, Doherty, Rumble, Bunn \& Butler, was a former Attorney General of the United States (1929-1933). Dodge, a former assistant attorney general for Massachusetts and a former president of the Boston Bar Association, was a niember of Palmer, Dodge, Chase \& Davies, a Boston corporate firm. Donworth, a former federal district court judge, was a unember of the Seattle firm of Donworth, Paul and Donworth. Gamble was a corporate and banking lawyer from Des Moines, Iowa. Monte Lemann, a lawyer from New Orleans, was instrumental in opening the first legal aid society in that city; he later served on the first board of directors of the national Legal Aid and Defenders Association. See Frankfurter, $A$ Legal Triptych, 74 Harv. L. Rzv. 433, 445-47 (1961). Loftim, who served as President of the American Bar Association from 1934 to 1935, had a corporate practice in Florida. Appointed to the Senate to serve out the term of deceased Senator Park Trummel, Loftin spent part of 1936 in Congress representing Florida in the Senate; he did not seek election after the expiration of his appointed term. See Scott M. Loftin, 1878-1953, 39 A.B.A. J. 982 (1953). Olney had served as an associate justice of the California Supreme Court and was a member of a San Francisco firm. Tolman, a member of a Chicago law firm, was also Special Assistant to the Attorney General of the United States from 1934 to 1938; he was the editor of the ABA 
odds with those made by their contemporary counterparts. ${ }^{25}$ Why were these gentlemen, often associated with interests linked today to the "defense bar," sounding (from our latter-day perspective) like "plaintiffs" " lawyers? Why did they provide a structure of rules that, in combination with other factors, permitted the federal courts to open their doors to a new host of rights seekers? ${ }^{26}$ It was these gentlemen, after all, who drafted the rules of discovery that have shone a beacon on corporate and government practices. ${ }^{27}$ It

Journal from 1921 to 1946. See Major Edgar Bronson Tolman Dies at 88, 33 A.B.A. J. 1188 (1947). Wickersham, who served only a short time before his death in 1936, was President of the American Law Institute and had been Attorney General of the United States from 1909 to 1913. Chandler, supra note 1, at 492, 493 n.62. Pepper, who replaced Wickersham, was a former United States Senator and a member of the Philadelphia bar. George Pepper, PHILADELPHIA LAWYER: AN AUTOBIOGRAPHY 343-83 (1944).

The law professors on the Advisory Committee represented several universities. Cherry, from the University of Minnesota, taught contracts and evidence. AALS DIREcToRY OF TEAchers IN MEMBER Schools 37 (1935) [heremafter cited as AALS Directory]. Clark, the Committee's reporter and one of its most enthusiastic propagandists, was Dean of Yale Law School; he later became a judge on the Court of Appeals for the Second Circuit. See Smith, supra note 22, at 915. Dobie, who had written a leading treatise on federal procedure, was Dean of the University of Virginia Law School. Armistead Dobie, Handbook of Federar Jurisdiction AND Procedure (1928). Morgan was an evidence professor at Harvard, and the reporter for the American Law Institute's Model Code of Evidence. He subsequently coauthored a book which argued that Sacco and Vanzetti had been wrongly convicted. See L. Joughin \& E. Morgan, The Legacy of Sacco \& VanzetTi (1948). Sunderland, a law professor at the University of Michigan, taught courses on judicial administration and on pleading. AALS DiREcToRy, supra, at 137. He frequently wrote in support of the Rules, particularly with regard to the pretrial process and discovery.

These practitioners and academics were involved in other areas of law reform as well. As of 1942, Dodge, Donworth, Lemann, Mitchell, Pepper, and Tolman were all members of the Council of the American Law Institute (ALI). Cherry and Morgan were members of the ALI Committee on Evidence; Clark and Dodge were consultants to that committee. MoDEL Code of Evidence at iii (1942).

Most of the Advisory Committee members were in their fifties and sixties; a few were in their seventies. Clark was the youngest at age 46 .

${ }^{25}$ By "countcrparts," I mean those who occupy parallel positions within the social structure. Some of these "parallelisms" may be superficial, however. For example, the American Bar Association, now an established entity, was still in the midst of becoming powerful during the years leading up to the promulgation of the Federal Rules. See Matzko, "The Best Men of the Bar": The Founding of the American Bar Association, in ThE NEw HIGH Priests: Lawyers in Post-Crvil War America 75 (G. Gawalt ed. 1984) (ABA as expressive of late nineteenth century reformist interests); Roscoe Pound, The Lawyer From ANTiQUITY To MoDern Trmes 270-71 (1953) (discussing the revival of professional organizations).

${ }^{28}$ Clark was sensitive to these political aspects. He attempted to assuage those fearful that liberal discovery rules would "permit . . . the inanufacturing of evidence" by responding that the rules were "one of the greatest engines for securing the trust at once from a witness or a party and thereafter holding him to it." Clark, The Bar and the Recent Reform of Federal Procedure, 25 A.B.A. J. 22, 23 (1939) [hereinafter cited as The Bar].

${ }^{27}$ See, e.g., In re United States of America, Socialist Workers Party v. Atterney General, 565 F.2d 19 (2d Cir. 1977) (obliging the FBI to permit plaintiffs' attorneys to inspect its files about its infiltration of the Socialist Workers Party and Young Socialist Alliance; 
was these gentlemen who wrote the precursor of the class action rule that has aided (to some extent) the vindication of group rights. ${ }^{28}$ It was these gentlemen who insisted on abandoning technicalities so as to enable consideration of the merits of individuals' claims. ${ }^{29}$ In the nineteen-thirties, the drafters of the Federal Rules of Civil Procedure made choices to relax pleading rules, to require information exchange, to make litigation easier. ${ }^{30}$ Today, many of

the attorneys were required to maintain confidentiality), cert. denied, 436 U.S. 962 (1978); Parsons v. General Motors Corp., 85 F.R.D. 724 (N.D. Ga. 1980) (permitting discovery of crash-test results in defective-design suit); Paul Brodeur, Outrageous Misconduct: The Asbestos Industry on Trial ch. 4 \& passim (1985); D. HensLer, W. Felstiner, M. Selvin \& P. Ebener, Asbestos in the Courts: The Challenge of Mass Toxic Torts (1985); Franklin, Suit Unveils 9-Year Company Debate on Warning for Toxic Paint Additive, N.Y. Times, Aug. 4, 1981, at B7, col. 1.

2s As promulgated in 1938, Rule 23 defined limited categories of class actions. Major revisions of the rule-and of third party practice in general-occurred in 1966. See FeD. $R$. Crv. P. 19, 23, 23.1 \& 24, as amended by Order Amending Rules of Civil Procedure, 383 U.S. 1029, 1045, 1050-51 (1966). See generally Kaplan, Continuing Work of the Civil Committee: 1966 Amendments of the Federal Rules of Civil Procedure (pts. 1 \& 2), 81 HaRv. L. REv. 356, 591 (1967).

19 Clark explained that the new federal rules were "but means to an end, the enforcement of substantive justice"; he claimed that "one result of the rules is that it is very hard to make a mistake which will finally prejudice your rights." Clark, Fundamental Changes Effected by the New Federal Rules I, 15 TENN. L. REv. 551, 551 (1939) [hereinafter cited as Fundamental Changes]; see also Clark, The Bar, supra note 26, at 24 ("the very liberality of the rules" should not be used "to resurrect the old technicalities of formal pleading"); Moore, The Place of the New Federal Rules in the Law School Curriculum, 27 Geo. L.J. 884, 892 (1939) ("Procedure can go forward with the principles of 1939"). Sunderland, more restrained in his rhetoric, made the same points. Sunderland, The New Federal Rules, 45 W. VA. L.Q. 5, 30 (1938) ("The purpose . . . is to elimmate technical matters by removing the basis for technical objections, to make it . . . difficult . . . for cases to go off on procedural points, and to make litigation as inexpensive, as practicable and as convenient, as can be done.").

so It is admittedly difficult to determine how much of the credit for the liberality of practice under the Rules should properly go to the drafters. In some cases, Supreme Court interpretation of the Federal Rules has been a critical factor in creating a degree of liberality that may not have been intended by the drafters. For example, Charles Clark advocated the use of summary judgment to dispose of non-meritorious claims; he was concerned that courts were too hesitant in using that rule. See, e.g., Clark, The Influence of Federal Procedural Reform, 13 LAw \& Contemp. Probs. 144, 158 (1948) [hereinafter cited as Procedural Reform]; Clark, Summary Judgments and a Proposed Rule of Court, 25 J. AM. Judicature Soc'y 20, 20-22 (1941); see also Smith, supra note 22, at 929-31 (describing Clark's effort to apply summary judgment liberally during his tenure on the Second Circuit). In contrast, at least until recently, the Supreme Court has refused to permit summary judgment unless the moving party sustains the burden of proving "the absence of a genuine issue as to any material fact." Adickes v. S.H. Kress \& Co., 398 U.S. 144, 157 (1970). The Court's approach has recently come under attack, see Schwarzer, Summary Judgment Under the Federal Rules: Defining Genuine Issues of Material Fact, 99 F.R.D 465, 466 (1984) ("the rule has become encumbered with an impressionistic and dogmatic overlay that obstructs sound analysis"), and the Court may be relaxing its standards, see Matsushita Electric Industrial Co. v. Zenith Radio Corp., 106 S. Ct. 1348, 1357 (1986). 
these gentlemen's counterparts are attacking those very choices.

\section{A. The Drafters' Faith}

What animated those who worked on procedural reform in the nineteen-thirties? Were they progressive reformers who thought that, with professionals leading the way, they could structure a better society for all? Were they incipient New Dealers embarking on procedural reforms to serve their conception of the public interest? ${ }^{31}$ Were they committed to facts, as a source of accurate description and of normative insight? Were they reacting to the challenge of legal realism by attempting to reestablish the "rule of law" through a codification of procedure? Or were they simply advancing their narrow self-interests by protecting the clients they represented (largely financial and business interests) and the groups they led (such as the American Bar Association ${ }^{32}$ )?

It seems, in hindsight, that answers lie in all these directions (and more ${ }^{33}$ ). For example, Charles Clark, one of the dominant voices in the rulemaking group, had a wide-ranging and untraditional set of views. Clark was a committed reformer who saw lawyers as important contributors to the public welfare. ${ }^{34}$ Years after the Federal Rules became effective, Clark bragged about the role that lawyers, and lawyers alone, had played in the formulation of the Federal Rules. ${ }^{35}$ Further, soon after Clark had assisted in the

Later amendments to the Rules have also made major contributions to the liberality of federal procedure. The 1966 amendments abolished the distinctions among "true," "hybrid," and "spurious" class actions. FED. R. Crv. P. 23 (as amended by Order Amending Rules of Civil Procedure, 383 U.S. 1029 (1966)). These revisions have had a profound effect on civil litigation. See Yeazell, From Litigation to Class Action, Part II: Interest, Class, and Representation, 27 UCLA L. Rev. 1067, 1107-20 (1981). The 1966 revisions also reformulated the rules for joinder and intervention. See Fed. R. Crv. P. 19 (jomder); id. 24 (intervention) (as amended by Order Amending Rules of Civil Procedure, 383 U.S. 1029 (1966)). My sense is that, when the drafters spoke of joinder, they had in mind the combining of claims perceived to have been artificially split by the distinction between law and equity-and not the Calder-like configurations we call "cases" today. For a discussion of the impact of the 1966 amendments, see Kaplan, supra note 28, at 386-94.

s1 Subrin, The New Era in American Civil Procedure, 67 A.B.A. J. 1648, 1651 (1981) ("The federal rules ultimately were passed as New Deal legislation").

32 Of course, then as now, neither the advocates of rule reform nor the organizations with which they are affiliated should be too readily equated with a single set of interests.

ss See Burbank, supra note 1, at 1106 (the goal of allocatimg power between the courts and Congress); Subrin, The Federal Rules of Equity Procedure: An Historical Perspective 15-16 (May 14, 1986) (unpubhished manuscript on file with The University of Chicago Law Review) (thoughtfully addressing how the drafters adopted equity rules' philosophy).

34 See Clark, The Bar, supra note 26, at 22.

${ }^{35}$ Clark, The Role of the Supreme Court in Federal Rule-Making, 46 J. AM. JuDrCATURE Soc'y 250, 254 (1963) [hereinafter cited as Role of the Court] (rule reform was "a 
rule reform, he urged the bar to take up, as one of its next causes, provision of legal services for those unable to pay. ${ }^{36}$ Clark was also involved in developing information about the courts. Relatively early in his career, he was intrigued by the contributions that field (today "empirical") research could make to the legal process;";7 facts held great sway with him. Clark also had some interest in and involvement with the legal realism movement, ${ }^{38}$ but his public papers suggest that Clark believed that law existed apart from what the judges "ate for breakfast." 39 In contrast to Clark's ideological approach, others involved with the rule drafting seemed to take a more self-interested approach. As lawyers representing clients in more than one state, they bemoaned tlie lack of uniformity in federal practice, and they lielped craft a reform that has aided tlie growtll of multi-state practices. ${ }^{40}$

In short, many agendas emerge from the pubhshed writings of the drafters. Some of their efforts were aimed at "slaying the drag-

lawyer's job and it has been accomplished with a lawyer's skill"). See generally Wright \& Reasoner, Introduction to Charles Clark, Procedure-The Handmaid of Justice (1965).

so See Clark, The Bar, supra note 26, at 24; Clark, The Function of Law in a Democratic Society, 9 U. CHI. L. REv. 393, 400-01 (1942) [hereinafter cited as Function of Law]. Such a concern was not widespread at the time. See infra note 83 and accompanying text.

37 See C. Clark \& H. Shulman, supra note 9 (study of Connecticut practice); see also Schlegel, American Legal Realism and Empirical Social Science: From the Yale Experience, 28 Bufralo L. REv. 459, 468-524 (1979) (describing Clark's involvement with several empirical studies of litigation and his growing appreciation for the complexity of doing field work).

so For Clark's views on the realist movement, see Clark, Function of Law, supra note 36, at 394-95 (praising the "cleansing breeze" of a new "frankness"); Clark \& Trubek, The Creative Role of the Judge: Restraint and Freedom in the Common Law Tradition, 71 YaLE L.J. 255 (1961) (critique of Llewellyn's The Common Law Tradition). For his participation in its work, see supra note 37; Clark, Douglas \& Thomas, The Business Failures Project-A Problem in Methodology, 39 Y ALE L.J. 1013 (1930). Clark was listed in Llewellyn's "sample" of realists. Llewellyn, Some Realism About Realism-Responding to Dean Pound, 44 Harv. L. Rev. 1222, $1226 \mathrm{n} .18$ (1931). For a discussion of the realists, see generally William Twining, Karl Llewellyn and the Realist Movement 56-83 (1973).

3* Cf. Jerome Frank, Courts on Trial 161-64 (1949). Clark was often in conflict with Jerome Frank when both served as judges on the Second Circuit. See Robert Glennon, The ICONOCLAST AS Reformer: Jerome Frank's IMPACT ON AMERICAN LAw 120-22 (1985) (describing Clark's objections to Frank's practice of sending his opinions, often with cover letters urging favorable review, to bis friends on the Supreme Court); Smith, supra note 22, at 94047 (discussing disagreement between Clark, who opposed piecemeal review, and Frank, who supported interlocutory appeals). See generally Marvin Schick, Learned Hand's CouRT 247-304 (1970) (discussing disputes between Frank and Clark).

10 Members of the ABA were champions of uniformity as a means to "diminish the expense and delay of litigation." Report of the Special Committee to Suggest Remedies and Formulate Proposed Laws to Prevent Delay and Unnecessary Cost in Litigation, $35 \mathrm{RE}-$ PORTS OF THE A.B.A. 614, 615 (1910) [hereinafter cited as Special Committee Report]; see Burbank, supra note 1, at 1040-45 (dissatisfaction with the Conformity Act and ABA efforts); id. at 1045-51 (ABA's growing involvement with the reform efforts). 
ons" of their procedural world: the felt needs for uniformity of federal practice across the country, ${ }^{41}$ for uniformity of practice between law and equity, ${ }^{42}$ for reducing the possibility of technical errors, $^{43}$ and for greater court (rather than legislative) control of rulemaking. Underlying these many goals is a consistent theme, with a highly emotional quality, that emerges from the published commentary. Many within the rule-drafting group gave public testimony in support of the procedural system they were creating. They claimed that the procedures they championed would enable judges or juries to render fair judgments. The "adversary system" was their shorthand for the procedures they sought to foster-a lawyer-based process in which each side was responsible for generating information to be used either by the parties (to reach an accommodation) or by judges and juries (to assess and then to impose an outcome). ${ }^{44}$ Taking into account the many pohtical

41 See, e.g., Tolman, The Origin of the Conformity Idea, Its Development, the Failure of the Experiment, the Evils which Resulted Therefrom, and the Cure for Those Evils, 23 A.B.A. J. 971 (1937); cf. Moore, Federal Rules of Civil Procedure: Some Problems Raised by the Preliminary Draft, 25 Geo. L.J. 551, 552-53 (1937) (discussing early drafting efforts, in which drafters from one state were often leery of practices of other states).

12 After the Rules Enabling Act was passed in 1934, the Supreme Court expressed its intention to promulgate uniform federal practice rules for law, leaving intact the Federal Equity Rules that had heen in place since 1912. See Order Promulgating Rules of Procedure for the Courts of Equity of the United States, 226 U.S. 629 (1912). Clark and Moore wrote an article in 1935 arguing for one set of federal rules for both law and equity. Clark \& Moore, A New Federal Civil Procedure-I. The Background, 44 Yale L.J. 387, 415-35 (1935). Their views, shared by others, persuaded the Court to charge the Advisory Committee with drafting a single, comprehensive set of rules. See Appointment of Committee, supra note 1; see also Simplifying Procedure in Federal Courts, 2 U.S.L.W. 866 (May 14, 1935) (address of Chief Justice Hughes to the American Law Institute); Clark, Procedural Reform, supra note 30, at 147 (discussing the early role of Chief Justice Taft). But see McCaskill, One Form of Civil Action, But What Procedure, for the Federal Courts, 30 Irt. L. REv. 415 (1935) (dissenting from Clark and Moore's advocacy of complete unity between law and equity pleading). For cases to which the Rules do not apply, see FED. R. Crv. P. 81.

43 See, e.g., Moore, supra note 29, at 886 (giving an example under the old system of pleading of how, "[q]uite naturally, first principles defeated justice"). Although the drafters did provide for some specific procedural rules for certain kinds of cases, see, e.g., FED. $R$. Civ. P. 4(d)(4) (service of process when the United States is a party), they were concerned with keeping distimctions to a minimum in the interest of simplified "scientific" procedure, see, e.g., A. DoBIE, supra note 24, at 590 (praising the then-proposed legislation that became the Rules Enabling Act). See also Fowler, A Psychological Approach to Procedural Reform, 43 YaLE L.J. 1254, 1255 (1934) (the need for flexibility).

4t As John Langbein reminds us, the core of our notion of the adversary system is the "advance[ment of] partisan positions." Langbein, The German Advantage in Civil Procedure, 52 U. CHI. L. REv. 823, 824 (1985). For Langbeul, continental traditions demonstrate that "the adversaries" role in fact-gathering" is not essential to adversarialism and that, even when court officials gather information, adversarial activities may still occur. Id. Nevertheless, many within the United States describe the responsibility of the parties for the collection and presentation of information as a part of adversarialism. I have adopted this 
purposes of the drafters' speeches and commentaries on the Federal Rules, ${ }^{45}$ the voices of these men suggest more than the massive sales effort in which they were in fact engaged. These men spoke as if they had a belief, fairly termed "faith," in adversarial exchanges as an adequate basis for adjudication, in adjudication as the essence of fair decisionmaking, and in fair decisionmaking as essential for legitimate government action. The rules that they crafted were to enable attorneys, facing off within the tradition of adversarial encounters, to provide information to judges who would, in turn, produce acceptable (indeed perhaps good) outcomes.

Today, it is hard to get in touch with such faith. Quoting Wigmore's description of cross-examination as the "greatest legal engine ever invented for the discovery of truth" often generates chuckles. ${ }^{46}$ Truth itself seems problematic, let alone the drama of the courtroom as a technique for achieving it. Even the words "engine ... for ... truth" suggest an unquestioning welcome of the industrial era that has been echpsed by an understanding that the "machine in the garden" commentary in the nineteen-thirties and forties generally lacks

common usage; the references here to the adversary system denote one in which the parties have the primary responsibility for preparing all aspects of their case. Further, although adversarial exchanges occur in other settings, such as administrative hearings, my focus, like that of the drafters and of many contemporary commentators, is on court-based activities.

is Senator Walsh, from Montana, is credited with blocking legislation that would have permitted uniform rulemaking; it was only after his death that the Rules Enabling Act was passed. See Clark, Procedural Reform, supra note 30, at 146-48 (explaining that some of Walsh's objections were well-grounded and that the final product was improved as a result of his criticisms); see also Burbank, supra note 1, at 1063-65, 1081-83, 1085-89 (discussing Walsh's opposition); Subrin, supra note 33 , at $94-98$ (Walsh was a progressive egalitarian fearful of unbridled judicial power).

Much of the commentary on the Rules, notably the many lectures given by Clark, was aimed at convincing the audiences of the utility and desirability of the new procedure. See, e.g., Clark, Fundamental Changes, supra note 29 (lecture given at Knoxville Symposium on Simplification of Legal Procedure). The advocates of the Rnles tried hard to dispel the notion that the Rules worked a "radical" change in civil procedure. See Special Committee Report, supra note 40 , at 616 . Nonetheless, at least one member of the Advisory Committee admitted that the

prescription of a single form of action as a substitute for separate proceedings at law and in equity is a big departure from a procedure to which many of us have been for a lifetime accustomed .... As to the outcome of the whole experiment, I an somewhat hopeful; but much will depend upon the willingness of bench and bar to adopt a cooperative rather than an obstructive attitude.

G. Pepper, supra note 24, at 381-83.

48 5 John Wigmore, A Treatise on the Anglo-American Systzm of Evidence in Trials at Common LAW § 1367, at 29 (3d ed. 1940).

47 Leo Marx, The Machine in the Garden: Technology and the Pastoral Ideal in AMERICA (1964) (analyzing the complex depiction of technology in United States' literature and examining teclinology's threat to the pastoral ideal). 
such a skeptical tone. ${ }^{48}$ For example, in the nineteen-forties, some of the rule drafters debated the wisdom of shielding notes made by attorneys (today called attorney "work product") from discovery. ${ }^{49}$ Speaking to the 1946 Conference of the Court of Appeals for the Third Circuit, George Pepper, a member of the Advisory Committee, advocated the inclusion of such a protection in the Rules. ${ }^{50}$ In rejecting the view that "parties to a lawsuit should join the court in a quest for ideal justice" through cooperation, he explained tbat "tbe Committee has assumed that approximation of Justice can best be reached in each litigated case if to some extent the case is in the nature of a warfare between the plaintiff and defendant."s1 The Rules were not intended to "abolish war" but only to civilize it. ${ }^{2}$ Pepper's discussion about the Rules assumed the feasibility of

48 No number of examples can "prove" the absence of skepticism. Further, I find it difficult to believe that ours is the generation that has discovered indeterminacy. But the rhetoric of the drafters of the 1938 Rules is instructive because it differs suhstantially from commentary offered today. See, e.g., Moscowitz, Trends in Federal Law and Procedure, 5 F.R.D. 361, 381 (1946) ("The increasing hberality of the Federal courts toward disregarding technicalities and the growing tendency to secure to individuals the privileges which are inalienable under our system of government are trends which portend fuller realization of moral justice under the law.").

19 Compare U.S. Supreme Court Advisory Comm. on Rules for Civil Procedure, Second Preliminary Draft of Proposed Amendments to Rules of Civil Procedure for the District Courts of THE United States, Proposed Rule 30, at 37-40 (May, 1945) [hereinafter cited as 1945 Proposed AmEndments] (proposing that judges he given express authority to place restrictions on discovery of work product, but rejecting an absolute privilege), with U.S. Supreme Court Advisory Comm. on Rules for Civi Procedure, Report of Proposed Amendments to Rules of Civil Procedure por the District Courts of the United States, Proposed Rule 30, at 39 (June, 1946) [hereinafter cited as 1946 Proposed AmendMENTS] (proposing that the rule be amended to bar discovery of work product unless "denial . . . will unfairly prejudice the party seeking the production"). See also id. at $40-47$ (dis-. cussing the work-product contróversy).

The Supreme Court did not promulgate the proposed 1946 work product amendment. See Order Amending Federal Rules of Procedure, 329 U.S. 843 (1946) (not including the proposed amendment to rule 30 ). However, the Court did hold in Hickman v. Taylor, 329 U.S. 495 (1946), that the Rules do not "justify unwarranted inquiries into the files and the mental impressions of an attorney." Id. at 510. The Court's rationale was the same as the Committee's: the need to inamtain the incentives and rewards of adversarialism. Compare 1946 Proposed Amendments, supra, at 46-47, with Hickman, 329 U.S. at 510-14. Had Hickman come out the other way, contemporary litigation problems would look very different. For the suggestion that the reach of Hickman should be narrowed, see Waits, Work Product Protection for Witness Statements: Time for Abolition, 1985 Wis. L. REv. 305, 310 (1985) ("Witness statement immunity is sunultaneously the most expensive and the least justifiable category of work product protection.").

so Discovery Procedure Symposium Before the 1946 Conference of Third United States Circuit Court of Appeals, 5 F.R.D. 403, 403-07 (1946) [hereinafter cited as Third Circuit Discovery Symposium].

s1 Id. at 404.

32 Id. The opposing view was articulated by Abraham Freedman, the lawyer who had argued in favor of disclosure in Hickman. Freedman contended that "courts ought to move 
"steer[ing] a course between the two extremes"-of preserving "the features of an adversary proceeding" while at the same time limiting the pursuit of "individual iuterest." $5 s$

To the conteinporary ear, it is incongruous to find a pledge to adversarialism in the midst of a discussion of the discovery rules. Today's distress with discovery stems, in large measure, ${ }^{54}$ from the all-too-obvious tensions between the duty of "zealous advocacy" and the obligations of cooperative information exchange. While technological clianges such as photocopiers and computerized data systems could not readily have been anticipated, surely tlie drafters must have foreseen some of the conflicts attorneys could generate by exploiting discovery practice. Why, when faced with the first major issue about discovery, did they (the Supreme Court and the Advisory Committee ${ }^{\mathrm{ss}}$ ) protect attorneys? Why didn't tliey see that the logic of tlieir own arguments about the utility of discovery required serious restrictions on adversarialism as tliey had known it? Why didn't tliey know what we can now so readily see? ${ }^{\text {se }}$

heaven and earth to develop the real facts so that justice will be handed out," that such was the intent of the Federal Rules, and that the proposed amendment to protect attorneys undercut the Rules' commitment to facts as a predicate to justice. Id. at 425-26.

It may well be that some members of the Committee (such as Morgan and Sunderland) had initially envisioned that the Rules would significantly alter adversarialism. But by the 1940s, popular sentiment made such a stance, in Pepper's words, "unrealistic." Id. at 404. See generally Armstrong, Report of the Advisory Committee on Federal Rules of Civil Procedure Recommending Amendments, 5 F.R.D. 339, 356 (1946) ("There is no Amendment about which there is a greater or stronger division of opinion among members of the Bar.").

s2 Third Circuit Discovery Symposium, supra note 50, at 404. Later in the discussion, in response to a comment by a defense lawyer, Mr. Pepper suggested that as an "unreconstructed practitioner," he personally would have preferred that attorneys be given even more protection. 'He said, however, that "[y]ou have got to look at the thing practically," as an attempt to move tbe committee to "a compromise between the extreme views." Id. at 431; cf. Morgan, Foreword to Moder Code of Evmence 11 (1942) (the Model Code "recognizes tbe merits of the adversary system but discountenances its excesses").

* The sources of contemporary distress about discovery are complex, and the empirical bases for the conclusion that tbe discovery system has been "abused" are limited. See Friedentbal, A Divided Supreme Court Adopts Discovery Amendments to the Federal Rules of Civil Procedure, 69 CALIF. L. Rgv. 806, 810-15 (1981) (discussing the political bases of some Justices' interest in discovery reform).

ss See supra note 49.

se Two obvious answers deserve mention. First, our appreciation of the difficulty in describing the quantum of information appropriately provided and that permissibly withheld bas been shaped by our experience with the Rules. See, e.g., Shapiro, Some Problems of Discovery in an Adversary System, 53 Minv. L. REv. 1055, 1093-1100 (1979) (attorneys' responses to questionnaires about discovery demonstrated wide variance in readimg wbat the Rules mandated). Second, the drafters may well have been aware of such problems but thought that the Rules were not the place in which to respond. See Burbank, supra note 1, at 1106-07 (the enabling legislation intended to demarcate splueres of authority between Congress and the Court). 


\section{B. Their World and Ours}

Of course, the simple answer is that so much has changed in the last fifty years that their world view and ours are quite different. But probing exactly how the world (and more specifically, the world of litigation) has changed will help guide our current considerations of the Rules. The public commentary of the nineteen-thirties suggests that, when writing their Rules, the drafters held a series of assumptions about the kinds of cases litigated in federal court, the possibilities of professionalism, and the scope of the judicial role. Although these men were framing Rules to accommodate the new society that some of them subsequently participated in shaping, these men also reflected the litigation world from whence they came. As a consequence, I believe, one of the prototypical lawsuits for which the 1938 Federal Rules were designed was the relatively simple diversity case: a dispute between private individuals or businesses in which tortious injury or breach of contract was claimed, private attorneys were hired to represent the parties, and monetary damages were sought. ${ }^{57}$

By suggesting that the private monetary dispute was one of the paradigm cases underlying the Rules, I am not arguing (nor could I, given my beliefs about the limits of listorical inquiry and given my reliance upon the published literature) that the drafters had such a case exclusively and specifically "in mind" at all times as they wrote the Rules. Indeed, from the Rules and the commentary, we know that tlie drafters had other cases "in mind" as well. Equity cases were critical to their enterprise; a major stated purpose of the new Rules was to provide unified procedure for law and equity. ${ }^{58}$ Furtlier, these were the years when labor injunctions and receiverslips were used with some frequency, ${ }^{59}$ and the drafters were surely aware of such cases as they worked. Moreover, some if not all of the drafters knew that a substantial part of the federal

${ }^{67}$ For a critique of models of adjudication based on tbe traditional private civil lawsuit, see Fiss, The Social and Political Foundations of Adjudication, 6 Law \& Hum. BeHav. 121, 121-22 (1982) ("structural reform" in addition to "dispute resolution" is a basic model of adjudication). For a discussion of the influence of other kinds of cases as paradigms, see Subrin, supra note 33 , at 63.

${ }^{8 s}$ See Clark \& Moore, supra note 42, at 415-35 (urging the complete unity of law and equity practice). The drafters also sought to select the "best" rule from the diverse practices in many states, see, e.g., 1 P. EDMUNDs, supra note 9, at 113-20 (search for best method of commencing lawsuits), and to avoid the complexity of the past-perceived as technicality run amok, see Clark \& Moore, supra note 42 , at 392 . For the view that the drafters were interested in adopting equity modes to give judges greater authority, see Subrin, supra note 33 , at $36,38-55$.

69 See generally O. Fiss \& D. Rendleman, InJunctions (2d ed. 1984). 
docket was devoted to cases in which the United States (rather than only private citizens) was a litigant. ${ }^{60}$

In 1934, the American Law Institute (ALI) published a study of the business of the federal courts. ${ }^{61}$ The ALI surveyed civil cases in thirteen federal district courts in 1934 and documented that the United States was a party in a substantial percentage of the cases. For example, of the 9,852 civil cases (drawn from the law, equity, and admiralty dockets) reviewed, the United States was a party in 57.5 percent. $^{62}$ In contrast, the number of diversity cases was relatively small-some 18 percent of the cases surveyed. ${ }^{63}$ Thus, despite the by-then growing complaints that diversity jurisdiction was overburdening the federal courts, diversity cases were far outstripped by other kinds of filings. ${ }^{64}$

Some of the researchers involved in the ALI study were also a part of the group that drafted the Federal Rules. ${ }^{68}$ Charles Clark played a major role in both enterprises, and it is fair to assume that ALI data were readily available to the drafting committee. Moreover, some of the Rules were written to apply specifically to

so See Appendix A: Estimated Percentage of Civil Cases in Which the United States Was a Party, 1900-1984.

61 The ALI study marked an important step in improving recordkeeping in the federal courts. From 1873 until 1939, the Attorney General of the United States had the responsibility for collecting data on the federal courts and issued Annual Reports. Act of Mar. 3, 1873 , ch. 238 , § 1, 17 Stat. 578 (codified as amended at 28 U.S.C. $\$ 522$ (1982)). In the 1920s, interest in data collection grew. In some law schools, a series of pilot projects were begun to collect information on courts' caseloads. Clark, intrigued by empiricism, collected data on both state and federal court systems. See Schlegel, supra note 37, at 495-519; see also C. Clark \& H. ShuLman, supra note 9 (study of the Connecticut courts). The most comprehensive project in the 1930s was the ALI study that described civil and criminal cases in 13 federal district courts. American Law Institute, A Study of the Business of the Federal Courts, Part I, Criminal Cases (1934); id. Part II, Civil Cases (1934) thereinafter cited as ALI Crvil Cases]. The ALI called for improved data bases, and in 1939, Congress responded by establishing the Administrative Office of the United States Courts. Act of Aug. 7, 1939, ch. 501, $\$ 304,53$ Stat. 1223 (codified as amended at 28 U.S.C. $\$ 604$ (1982)).

62 ALI CiviL CAsEs, supra note 61, at 47. For statistics on the percentage of cases from 1871 to 1932 in which the United States had heen a participant, see id. at 111 (Detailed Table 1).

63 Id. at 47 . Of the 1,816 diversity cases surveyed, $82.2 \%$ were filed on the law side, while $17.8 \%$ sought equitable rehef. Id. at 56 .

st As noted by Wickersham (who headed the ALI at that time) in his foreward to the ALI study, "the facts found . . . with respect to . . . diversity of citizenship, afford a very strong basis for a surmise that the assertion so often made in Congress and elsewhere that these cases constitute a large proportion of the busiuess of the Federal District Courts . . . is not supported by the facts." Id. at 3; see Schlegel, supra note 37, at 508.

os In 1935, ALI's president (Wickersham), one of its vice presidents (Pepper), and several members of its council (Dodge, Lemann, Mitchell, and Tolman) were also members of the Rules Advisory Committee. After Wickersham's death, Pepper took his place in both positions. G. PEPPER, supra note 24, at 378-80. 
the United States as litigant. ${ }^{66}$ But the public discussion of the Rules was not peppered with references to government cases. Despite the ALI's statistics, the United States as litigant was an image rarely invoked. Rather, the focus of the public exposition of the Rules was upon their utihty in the private civil damage action.

Despite its empirical inaccuracy, the prevalence of the private damage action as a paradigm case in the public commentary makes a good deal of sense. First, many of the drafters of the Rules and most of the audiences_bar associations in the main ${ }^{67}$-to whom the drafters spoke were from the private sector. The drafters' advocacy, shaped by the concerns of those whom they hoped to persuade, claimed that the Rules would well serve private lawyers' needs. ${ }^{68}$ Second, to the extent that the statistical information about the United States as a frequent litigant was known, it may well have been discounted. A substantial portion of the hitigation was devoted to "hiquor cases," seen as the unfortunate results of prohibition and happily to be left behind with its repeal. ${ }^{69}$ Other cases involved internal revenue and food and drug enforcement, ${ }^{70}$

\footnotetext{
Be See, e.g., FED. R. Crv. P. 4(d)(4) (service of process when the United States is a party).

67 Clark stated that, in his trips across the country to promote the rules, he addressed more than 5,000 attorneys. Clark, Fundamental Changes, supra note 29, at 551; see also Federal Rules of Civil Procedure: Proceedings of the Institute at Washington, D.C., Oct. 6-8, 1938, AND OF THe Symposium At New YoRk CITY, Oct. 17-19, 1938 (E.H. Hammond ed. 1939); Rules of Civil Procedure gor the District Courts of the United States with Notes as Prepared under the Direction or the Advisory Committee and Proceedings of the Institute on Federal Rules, Cleveland, Ohio, July 21-23, 1938 (W.W. Dawson ed. 1938).
}

68 Little effort had to he expended to convince the federal government to support the Rules; the government had been involved with the drafting and had advocated support for the enterprise. Initially, the Department of Justice was considered as the body to be charged with rule drafting. See Chandler, supra note 1 , at 488-92. When the Supreme Court turned instead to an Advisory Committee, it included Edgar Tolman as one of its members and as the "representative" of the Justice Department. The draft rules had the approval of Homer Cummings, who served as the Attorney General from 1933 to 1939. See Address of Attorney General Cummings to Judicial Conference, Fourth Circuit, 21 A.B.A. J. 403 (1935); Cummings, Modernizing Federal Procedure, 24 A.B.A. J. 625, 627 (1938); see also Burbank, supra note 1 , at $1095-97$.

69 See Wickersham, Foreword to ALI Crvil CaSEs, supra note 61, at 3 (claiming that with the repeal of prohibition, "a very large part of the business of the Federal Courts" would abate). Wickersham's optimism about the decline in "liquor cases" was borne out by the data. In fiscal year 1933, more than 11,000 cases were commenced under the National Prohibition Act; in fiscal year 1934, that number dropped to 923 . ANNuAL REPORT OF THE AtTorney General of the United States, at 142, Exhibit 2 (1933) (Civil Cases to Which the United States Was a Party) [hereniafter cited as Annual Report; id. at 174 (1934).

7o See AnNual Reports, supra note 69 (1928-1938). A large portion of litigation today to which the United States is a party is similarly relatively invisible. See 1984 ADMrNISTRATIVE OFFICE Report, supra note 6, at 132-33, 256 (2.7\% of the 1984 cases to which the 
not intrinsically high visibility activities. In contrast, diversity cases had a special saliency and political significance in the nineteen-thirties, ${ }^{71}$ a period marked by concern with the effect of the diversity caseload on federal-state relations. 1938 was the year both of the Federal Rules of Civil Procedure and of Erie $v$. Tompkins. ${ }^{22}$

Third, the images that shape our thoughts are often not based upon statistical data. Rather, we are drawn to "vivid" information, which is typically not that presented in tabular form. ${ }^{73}$ This phenomenon is evident not only from the conversations of a half century ago but also from the contemporary commentary about procedure. Two kinds of cases have fueled debate about current reforms. One is the large scale "public law" or "structural reform"74 lawsuit. The other is the complex, multi-party action (the "Big Case"75) that includes months of discovery and the prospect of a lengthy trial. Both kinds of cases are statistical rarities on the federal docket ${ }^{78}$ but lave nonetheless captured the debate. A similar "vividness" phenomenon can be seen in the current discussion of the frequency of adjudication as compared to settlement. Many of today's commentators claim a 95 percent settlement rate because 5 percent of the cases filed in federal court are tried. Trial is the vivid adjudicatory process. What is ignored is the substantial volume of non-trial adjudication; some 35 percent of all federal cases

United States was a party were Federal Tort Claims Act cases, $2.7 \%$ were student loan recoupment actions, $3.4 \%$ were tax collection activities). Similarly, although $27 \%$ of the cases to which the United States was a party involved social security issues, our attention is captured by the class action social security cases that challenge the practices by which the agency operates. See, e.g., Lopez v. Heckler, 725 F.2d 1489 (9th Cir. 1984); rev'd, 105 S. Ct. 583 (1984).

${ }^{7}$ See, e.g., Clark, Diversity of Citizenship Jurisdiction of the Federal Courts, 19 A.B.A. J. 499, 503 (1933) ("[W]hile congestion of the federal courts resulting from the diversity cases is perhaps not proved, . . . their number, in the hight of their controversial nature, is substantial."). For a critique of diversity jurisdiction, see S. REP. No. 530, 72nd Cong., 1st Sess. (1932); Frankfurter, Distribution of Judicial Power Between United States and State Courts, 13 CoRnell L.Q. 499, 522-30 (1928).

72304 U.S. 64 (1938).

72 See R. NisbetT \& L. Ross, Human InfrRence Strategy and Shortcomings of SoCIAL JUDGMENT 43-62 (1980).

14 See Chayes, The Role of the Judge in Public Law Litigation, 89 Hanv. L. Rzv. 1281 (1976); Fiss, The Supreme Court, 1978 Term-Foreword: The Forms of Justice, 93 Harv. L. REv. 1, 2 (1979).

78 See, e.g., Langbein, supra note 44 , at 825.

76 See 1984 Administrative OfFice REPoRT, supra note 6, at 134 (diagram showing the distribution of civil cases by type). For example, in 1984 only $0.4 \%$ of the civil cases filed were class actions, $i d$. at 160 , and $2 \%$ involved securities or antitrust claims, $i d$. at $253-55$ (extrapolated). 
are disposed of by rulings on motions for dismissal or for summary judgment. ${ }^{77}$

Finally, the dominance of the paradigm of private monetary disputes stems from the absence of the many events that have caused us to change our paradigms; today, very different images come to mind when we think about the federal court docket. A myriad of developments-in legislation, constitutional interpretation, and procedural rulemaking - has given federal litigation a different complexion. The nineteen-thirties were the years before the New Deal legislation was firmly in place, before the surge of centralization of federal power. This was the era before implied private causes of action, before the rise of civil rights hitigation, before much federal court hospitality towards rights seekers, before intensive litigation against federal agencies, before the reformulation of the class action rule, before the "due process" revolution. This was the era before securities and antitrust class actions, before those multi-partied, multi-issued lawsuits whose existence depends, in part, on the 1938 Federal Rules. ${ }^{78}$

Given a paradigm of private damage actions, some of the basic choices embedded within the 1938 Rules make considerable sense. First, the decision to write a single trans-substantive set of rules is particularly appealing if one discounts discontinuities among kinds of cases. With a single paradigm, it is easier to overlook the saliency of the distinctions among various kinds of cases and hence to underestimate the need for rulemaking to take variation into account. ${ }^{79}$ Second, by positing a private dispute between property owners or between an injured individual and an alleged wrongdoer,

${ }_{77}$ Conversation with David Gentry, Administrative Office of the United States Courts (March 21, 1986).

${ }^{78}$ Changing procedural rights reflect and inspire changes in basic understandings. For example, prior to the late 1960s, federal courts often responded with a "hands-off" attitude towards prison litigation. Kaufman, Foreword to 2 PRISONERS' RIGHTS SourcerooK at ix (I. Robbins ed. 1980); see also Note, Beyond the Ken of the Courts: A Critique of Judicial Refusal to Review the Complaints of Convicts, 72 YALE L.J. 506 (1963). The change in posture towards that type of litigation affected our understanding of the role of courts and, along with other civil rights litigation, gave new meaning to the "pubhi" nature of "civil" cases. For thoughtful analysis of the interdependence of social conditions and procedural devices in the class action context, see Yeazell, Group Litigation and Social Context: Toward a History of the Class Action, 77 CoLum. L. REv. 866 (1977), and Yeazell, From Group Litigation to Class Action, Part I: The Industrialization of Group Litigation, 27 UCLA L. REv. 514 (1980).

${ }_{78}$ Trans-substantive rules were inspired by other concerns as well, including distress at the injustices worked by stringent pleading requirements, see, e.g., Moore, supra note 29, at $886-87$, and interest in permitting more discretion and authority to the professional judges, see Subrin, supra note 33, at 57-70. 
one may also be tempted to posit that the parties have resources, and in some cases, roughly comparable resources. In the context of rough comparability, a lawyer-based adversarial system has its strongest appeal. ("The [Advisory] Committee has not attempted to abohish war." ${ }^{\prime 80}$ )

To rely upon lawyer-based adversarialism, ${ }^{81}$ one must subscribe to a series of assumptions about the participants. First, proponents of this model must posit that the disputants are rational, competent actors who make deliberate decisions calculated to enhance their positions. Second, proponents must assume that the disputants have access to resources (in terms of dollars and of power) which in turn enable the generation of information and which give the disputants the opportunity to exercise choices among competing options. Third, when relying upon attorneys (to generate information, to relate information to their chents, and to be conduits of information from client to opponent and to court), the assumption is that the attorneys, acting as agents for disputants, have interests that coincide with those of their clients. A final, and central, assumption is that coinpetition between balanced opponents (these autonomous attorney-client units) will lead to the triumph of truth-or at least to the emergence of insights with normative power. With the two sides of a dispute more or less evenly matched, then at least in theory, the contest permits the "correct" winner to emerge.

These assumptions pervade the published commentary on the 1938 Rules. ${ }^{82}$ The drafters did not speak of the individuals who

${ }^{80}$ Pepper, Third Circuit Discovery Symposium, supra note 50, at 404.

-1 Compare Langbein, supra note 44, who argues for a limited version of adversarial litigation, in which primary responsibility for fact gathering is assigued to the court. If his version were commonplace and if the parties were to be relatively passive during the factfinding stage, then some of the assumptions set forth in the text could be relaxed.

${ }^{82}$ Return, for example, to the commentary about the work-product debate. The Advisory Committee's proposal in 1946 to protect attorneys appears animated by assumptions of equal access to information and the need to keep incentives high. The Committee recommended that judges consider whether information requested by opponents "penalizes the diligent" or "puts a 'premium on laziness." " 1946 Proposed AMENDMENTs, supra note 49, at 46-47. The Supreme Court's discussion of the problem in Hickman v. Taylor, 329 U.S. 495, 510-12 (1947), also rehed upon a vision of relatively comparable adversaries; rejecting the argument that individual plaintiffs were at a disadvantage when faced with corporate defendants, the Court said: "Discovery . . . is not a one-way proposition. It is available in all types of cases at the behest of any party, individual or corporate, plaintiff or defendant." 329 U.S. at 507. Subsequently, some of the rule drafters acknowledged some of the problems with their model. For example, in his 1955 Columbia lectures, Edmund Morgan, one of the members of the original Advisory Committee, noted that the "theory of our adversary system is attractive in statement . . . but it seldom fits the facts in modern hitigation," in part because of inequality of resources. He nonetheless concluded that the Federal Rules of Civil 
today draw some of our attention, the litigants without resources who lack attorneys ${ }^{83}$ or the litigants with indifferent, inattentive, or overly aggressive counsel. Once again, upon reflection, the differences between their sets of images and ours make sense. In the days of the drafting of the Federal Rules, many individuals without resources simply had no way of litigating cases. There was no Legal Services Corporation; there were fewer fee-shifting statutes and a smaller public interest bar. By and large, active litigants in the federal courts had to be those with resources. To the extent that poor plaintiffs were before the federal courts, the plaintiffs could have been represented on a contingency fee basis, and the lawyers would have provided some of the resources that their clients lacked. ${ }^{84}$ To the extent poor criminal defendants were before the federal courts, they lacked many of the "rights" that courts in subsequent years came to recognize. Moreover, the criminal side was considered a discrete phenomenon from the civil enterprise, ${ }^{85}$

Procedure had taken the "first step toward making a lawsuit a rational proceeding for discovery of the factual hasis of a controversy." Edmund Morgan, Some Problems of Proof UNDER the ANGlo-American System of Litigation 34-35 (1975) (reprint of 1955 Charpentier Lecture at Columbia Law School).

ss 'It dòes not appear that concern ab̆out the abilities of the impoverished to litigate was great when the Rules were formulated. See, e.g., Maynafd Pirsig, Cases and Materials on Judicial Administration 79 (1946) (devoting only a "note" to the problem that the "expense of litigation may result in the denial of justice to those unable to pay the cost"); id. at 968-1008 (chapter on "Agencies and Methods of Reform" does not mention problems of the poor as litigants). However, in 1919, the Carnegie Foundation did sponsor a study of legal services in the United States which in turn prompted some interest among the bar. See Reginald Heber Smith, Justice and the Poor (3d ed. 1924). In that volume, much of the discussion of "the needs of poorer people" focuses upon the provision of small claims court and an administrative remedies. Id. at ix (preface to the third edition by Henry Pritchett, President of the Carnegie Foundation). In the" study, Smith made a vehement plea for provision of services to the poor: "It must be possible for the humblest to invoke the protection of the law, through proper proceedings in the courts, ... or freedom and equality vanish into nothingness." Id. at 5.

84 For discussions of the complexity of lawyers as lenders to their clients, see Schwartz \& Mitchell, An Economic Analysis of the Contingent Fee in Personal-Injury Litigation, 22 StAN. L. REv. 1125 (1970). Cf. Kritzer, Felstiner, Sarat \& Trubek, The Impact of Fee Arrangement on Lawyer Effort, 19 LAw \& Soc'y REv. 251, 272 (1985) (in small cases, attorneys paid on an hourly basis put in more effort than do attorneys paid under a contingent fee arrangement; on larger cases, no significant differences emerged).

ss It is ironic that the rule drafters who saw a false dichotomy of "law" and "equity" appeared quite insensitive to the artificiality of the delineation "civil" and "criminal." $C f$. United States v. Ward, 448 U.S. 242 (1980) (deciding whether the penalties imposed by the Federal Water Pollution Control Act were "civil" or "criminal" and hence whether constitutional protections of criminal defendants could be invoked). In 1933, Congress authorized the Court to promulgate rules for criminal appellate cases, Act of Feb. 24, 1933, Pub. L. No. 371, 47 Stat. 904 (codified at 18 U.S.C. $\$ 3772$ (1982)), and in 1940, Congress authorized the Court to promulgate uniform federal criminal rules, Act of June 29, 1940, ch. 445, 54 Stat. 688 (codified as amended at 18 U.S.C. $\$ 3771$ (1982)); see Order Promulgating Rules of 
and the imbalance evidenced there would not have undermined the civil paradigm of fairly-matched adversarial encounters. ${ }^{86}$

Assuming a fight between individuals or corporations with resources, the drafters of the Federal Rules sought to make that fight more "fair," to diminish the technicalities and the distractions, to sharpen the focus on the merits. Take as a paradigm the private damage action, add hopes for legal professionalism and for the accessibility and utility of information, and then the faith in the lawyer-based, adjudicatory, adversarial procedure embodied in the 1938 Federal Rules makes sense.

\section{The Nineteen-Sixties and Beyond}

From their effective date in 1938 until the early nineteen-seventies, the Federal Rules of Civil Procedure received generally good press. While the rhetoric moved away from the initially gushing, laudatory comments ${ }^{87}$ to somewhat more subdued praise, ${ }^{88}$ the

Criminal Procedure for the District Courts of the United States, 323 U.S. 821 (1944); see also T. Clark, An Indorsement of Federal Rules of Criminal Procedure, 5 F.R.D. 305 (1946); Dession, The New Federal Rules of Criminal Procedure: I, 55 YALE L.J. 694 (1946).

ss I have not yet uncovered descriptions of how poor civil defendants fared against the United States as plaintiff. For discussions of legal services available to indigent litigants in other forums, see EMery Brownell, Legal AID IN THE UNITED STATES (1951); R. SMITH, supra note 83 . Smith's survey of legal aid organizations estimated that, by 1916,41 organizations provided services (primarily for wage claims and domestic issues) to 117,201 chents. Id. at xi. The majority of the organizations were financed by private charity, although nine cities provided some public support. Id. at 148. By 1949, 92 legal services organizations existed, E. BROWNBLL, supra, at 26 , and by $1959,79 \%$ of the cities with populations in excess of 100,000 had legal aid offices, $i d$., Supp. 1961, at 68. Once again, much of the funding came from private charity; in 1962, most of the 236 prograns nationwide were dependent upon

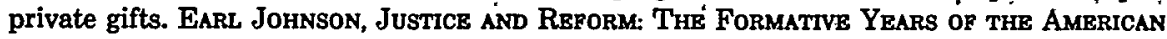
Legal Services Program 9-10 (1978). In 1967, federal funding became available and legal services increased substantially.

${ }^{87}$ See, e.g., Chandler, supra note 1, at 515 ("In truth the Federal Rules of Civil Procedure are probably the greatest single element of progress in the . . . federal trial courts in this century."); Clark, Procedural Reform, supra note 30, at 152 ("the universal chorus of approval is quite phenomenal"); Holtzoff, Instruments of Discovery Under Federal Rules of Civil Procedure, 41 Mrch. L. Rsv. 205, 224 (1942) (the Rules provide a "simple and efficacious means" of obtaining necessary information); Mitchell, Uniform State and Federal Practice: A New Demand for More Efficient Judicial Procedure, 24 A.B.A. J. 981, 983 (1938) (urging Illinois attorneys to follow the federal model and to "perfect" the judicial apparatus); Pike \& Willis, Federal Discovery in Operation, 7 U. CHI. L. RBv. 297, 327 (1940) ("[R]emarkably enough, the judges, casting off the old shackles, have apphed the new scope of examination [under Rule 37] almost hterally. Federal discovery is in operation."); Pike \& Willis, The New Federal Deposition-Discovery Procedure (pt. 1), 38 CoLuM. L. REv. 1179, 1180 (1938) ("[T]he new federal deposition-discovery practice affords the greatest opportunity for adequate trial preparation in the history of civil procedure.").

* Charles Clark remained exuberant. As late as 1963, he wrotc: "Viewed in perspective the success of the federal systcm is nothing short of phenomenal. Enthusiastic support has 
impression gleaned from the commentary is a positive one. The commentators saw the advantages of the Rules ${ }^{89}$ and generally endorsed the system that the Rules had structured. ${ }^{90}$

Moreover, during the nineteen-sixties, the belief in adjudicatory procedure that the Rules had espoused was adopted by the Supreme Court, indeed was "constitutionalized" in a variety of cases-most notably those involving criminal procedure and administrative law. Mandating a right to counsel in criminal cases and other rights for criminal defendants, ${ }^{92}$ the Court endorsed lawyer-based adversarial encounters as the mechanism for generating acceptable outcomes. Further, when obliging a state to provide a hearing prior to the withdrawal of welfare benefits, the Court expounded upon its faith in adjudicatory processes.

Goldberg v. Kelly ${ }^{93}$ stands as a striking illustration of a majority of the Court's equation of fair outcome with adjudicatory process. The "process" held to be "due" a welfare beneficiary prior to the withdrawal of benefits closely resembled courtroom procedure: notice, an opportunity to present witnesses, the right to confront and cross-examine adverse witnesses, and a statement of reasons rendered by an impartial decisionmaker who considered only the

long been a matter of ordinary knowledge. . . . No criticism of major character now appears." Clark, Role of the Court, supra note 35, at 254 (rejecting a critique by Justices Black and Douglas of the Court's role in rulemaking).

8s See Speck, The Use of Discovery in United States District Courts, 60 YALE L.J. 1132, 1155 (1951) ("discovery does appear to have fulfilled expectations in making information and evidence readily available to all parties"). But see Caskey \& Young, Some Limitations Upon Rule 33 of the Federal Rules of Civil Procedure, 28 VA. L. REv. 348 (1942) (advocating limitations on interrogatories); Rosenberg, Sanctions to Effectuate Pretrial Discovery, 58 CoLum. L. REv. 480, 497 (1958) (expressing concern about the "notable failings in .. . content and administration" of the discovery rules); Comment, Tactical Use and Abuse of Depositions Under the Federal Rules, 59 YaLE L.J. 117, 138 (1949) (concluding on the basis of confidential interviews with judges, attorneys, and court reporters that abuse-defined as expense, delay, and overly broad inquiries-occurred in complex litigation because of strategic exploitation of the Rules). See generally The Federal Rules of Civil Procedure: 1938-1958, 58 Colum. L. REv. 435 (1958).

20 The development of a standing Advisory Committee to oversee rule amendment was seen as a continuation of the rulemaking process and, at least by Clark, as a mechanism to keep the rules free from the encumbrances that judicial "glosses" could impose. Clark, "Clarifying" Amendments to the Federal Rules?, 14 OH10 ST. L.J. 241, 245, 247 (1953); see also Clark, The Proper Function of the Supreme Court's Federal Rules Committee, 28 A.B.A. J. 521 (1942).

91 Leubsdorf, Constitutional Civil Procedure, 63 Tex. L. Rev. 579 (1984).

92 See Gideon v. Wainwright, 372 U.S. 335 (1963); Gerstein v. Pugh, 420 U.S. 103, 114 (1975) (right to preliminary hearing); United States v. Wade, 388 U.S. 218, 236-38 (1967) (right to counsel at post-indictment lineup).

s3 397 U.S. 254 (1970). 
information presented at a hearing. ${ }^{94}$ Further, while the Court did not mandate counsel for welfare recipients, Justice Brennan surely wrote so that, if he could command a majority in the future, counsel would be the next right announced. "The right to be heard would be, in many cases, of little avail without the right to be heard by counsel," ${ }^{98}$ he said for the majority as he declimed to require state-provided lawyers but permitted counsel otherwise funded to attend the welfare termination hearings. As Goldberg exemplifies, during the fifties, sixties, and early seventies, the major cases about civil, criminal, and administrative procedure ${ }^{96}$ bespeak a commitment to adjudication that accords comfortably with the value choices expressed in the Federal Rules of Civil Procedure. The Court (and the Congress as well) took the model shaped by the imagery of a private civil damage action and transposed it to disputes between government and citizenry.

A major difficulty, however, anticipated but not decided by Court opinions of those years, was the problem of parity. Adversarialism is a plausible mechanism for generating information leading to acceptable outcomes and for validating individual dignity only when the adversaries are roughly comparable-when each side has similar resources. But, as is well known, many who attempt strategic adversarial interaction have few resources, hittle information, and disloyal, indifferent, or nonexistent agents. In the litigation world of the nineteen-sixties and thereafter, imbalance has become a visible norm, rather than an unstated exception or an invisible reality. ${ }^{97}$ When gross imbalances are commonplace and patent, a belief in adversarialism has a hollow ring. Hence, a major question for the nineteen-seventies was whether the Court (or sometimes Congress), having mandated adjudicatory procedure, would also require government subsidies or one way fee-shifting to

Id. at 267-68, 271.

${ }^{25}$ Id. at 270 (quoting Powell v. Alabama, 287 U.S. 45, 68-69 (1932)).

${ }^{26}$ See, e.g., Haimes v. Kerner, 404 U.S. 519 (1972) (liberal pro se pleading); Adickes v. S.H. Kress \& Co., 398 U.S. 144 (1970) (stringent requirements for the grant of summary judgment); Gideon v. Wainwright, 372 U.S. 335 (1963) (right to counsel); Douglas v. California, 372 U.S. 353 (1963) (right to counsel on appeal); Goss v. Lopez, 419 U.S. 565 (1975) (procedural safeguards prior to student suspensions); Morrissey v. Brewer, 408 U.S. 471 (1972) (procedural safeguards prior to parole revocation).

97 Earlier commentary did occasionally recognize the problems of the costs of legal services, of poor techniques for delivery of services, and of the disadvantages suffered by those without resources. See, e.g., Clark \& Corstvet, The Lawyer and The Public: An A.A.L.S. Survey, 47 YALE L.J. 1272, 1275-85 (1938) (survey of lower-class and middle-class access to lawyers); Llewellyn, The Uncovered Needs for Legal Service, 16 TENN. L. REv. 641, 648 (1941) ("If the charge at the toll gate to legal rights is too high, you have not got justice under the law!"). 
help fulfill the promise of adversarialism.

As is familiar, the answer has turned out, by and large, to be no-or, at least, not yet or not fully. In a series of cases, the Court has dechned to insist upon substantial subsidies to poor rightsholders to provide them with mechanisms to enforce those rights. Although holding that the Constitution required the waiver of filing fees for poor divorce plaintiffs, ${ }^{98}$ the Court did not order fee waivers for impoverished petitioners seeking discharges in bankruptcy $^{99}$ or for poor appellants seeking review of agency decisions that had reduced their welfare benefits. ${ }^{100}$ Although demanding the provision of counsel to indigent defendants faced with incarceration, ${ }^{101}$ the Court declined to insist upon free counsel for criminal defendants faced with fines ${ }^{102}$ or for every parent defending against the termination of parental rights. ${ }^{103}$ The Court has also turned a deaf ear to coinplaints about the adequacy of state-provided counsel in criminal cases; refusing to impose performance standards, the Court has erected herculean obstacles to claims of ineffective assistance of counsel. ${ }^{104}$

Congress has been inore forthcoming than the Court. In 1974, Congress created the Legal Services Corporation; ${ }^{105}$ in 1976, Congress enacted a major one-way fee-shifting scheme, the Civil Rights Attorneys' Fee Act, which provided an important source of funding for those who challenge state action on civil rights grounds. ${ }^{106}$ More recently, however, executive-sponsored initiatives have reduced the legal services program, ${ }^{107}$ and the Court has interpreted

${ }^{88}$ Boddie v. Connecticut, 401 U.S. 371, 374 (1971).

Or United States v. Kras, 409 U.S. 434, 449-50 (1973).

${ }^{100}$ Ortwein v. Schwab, 410 U.S. 656, 656 (1973).

101 Gideon v. Wainwright, 372 U.S. 335, $344-45$ (1963) (felonies); Argersinger v. Hamlin, 407 U.S. 25, 40 (1972) (any deprivation of hiberty regardless of classification of offense).

${ }^{102}$ Scott v. Illinois, 440 U.S. 367, 373 (1979) (actual imprisonment, not threat of inprisonment, is the "line defining the constitutional right to appointment of counsel").

${ }^{103}$ Lassiter v. Departnent of Social Servs., 452 U.S. 18, 31-32 (1981) (rejecting per se requirement of counsel).

104 "Criminal defendants who seek to overturn convictions because of incompetent counsel innst show not only incompetence, but also the likelihood that the outcome would have been different had competent counsel been provided. Strickland v. Washington, $104 \mathrm{~S}$. Ct. 2052, 2066-67 (1984). Moreover, such a showing nust be made on the record created by the inadequate attorney. Id. at 2069; see also Hill v. Lockhart, $106 \mathrm{~S}$. Ct. 366, 370 (1985) (Strickland test apphed to guilty pleas).

${ }^{108} 42$ U.S.C. $\$ \S 2996-2996 l$ (1982). For a critique of the program, see Abel, Law Without Politics: Legal Aid Under Advanced Capitalism, 32 UCLA L. REv. 474, 532-33 (1985).

10842 U.S.C. \& 1988 (1982).

107 See McDaniel, LSC, round five, 71 A.B.A. J., Mar. 1985, at 33 (the Reagan administration makes fifth annual proposal to eliminate funds for the Legal Services Corporation). Although the efforts to eliminate funding have been unsuccessful, the President has been 
the Civil Rights Attorneys' Fee Act to make its provisions less attractive. ${ }^{108}$

Waiver of access fees, government-financed representation, and one-way fee-shifting are not the only ways to subsidize poor litigants. Another technique is to focus on specific aspects of litigation, such as production of evidence. One option is to provide a direct subsidy. In a few instances, such as when an impoverished putative father lacked funds for a blood test, the Supreme Court responded favorably by ordering a state payment. ${ }^{109}$ However, the Court has carefully circumscribed the reach of such opinions, and other cases have etched the limitations of a "right" to state-funded evidence. ${ }^{110} \mathrm{~A}$ second way to reduce information costs is to rely upon information sharing; well-to-do opponents could be required to provide information to less well-heeled adversaries. Brady $v$. Maryland ${ }^{111}$ instituted a modest use of this approach in the criminal context; the Supreme Court obliged prosecutors to make exculpatory information available to the defense. However, of late the Court has retreated dramatically from Brady and has refused to enforce the prosecution's obligations to provide exculpatory information. ${ }^{112}$ In essence, the Court has only sparingly used information exchange or state-funded information creation as techniques for diminishing the imbalance between government and its opponents.

To summarize, placing faith in lawyer-based, adjudicatory. procedure makes some sense when there is a shared perception that the adversaries have the ability to compete. Game metaphors are plausible in tlie context of fairly-matclied teams. ${ }^{113}$ Upon a rec-

able to cut the LSC budget by more than one-third. Abel, supra note 105, at 533 .

${ }^{108}$ See Hensley v. Eckerhart, 461 U.S. 424, 440 (1983) (attorney's fee awards related to degree of success on particular claims); Marek v. Chesny, 105 S. Ct. 3012 (1985), discussed infra at text accompanying notes 166-72; Evans v. Jeff D., $106 \mathrm{~S}$. Ct. 1531 (1986), discussed infra at text accompanying notes 173-74.

${ }^{100}$ Little v. Streater, 452 U.S. 1, 16-17 (1981); see also Ake v. Oklahoma, 105 S. Ct. 1087,1099 (1985) (requiring provision of psychiatric assistance to aid accused, who meets...... specified criteria, in putting forward insanity defense).

110 See, e.g., Cahifornia v. Trombetta, 104 S. Ct. 2528, 2535 (1984) (no requirement that state preserve breath samples of allegedly intoxicated drivers).

111373 U.S. 83, 87 (1963). The German mode of procedure may offer a parallel potential and such a prospect would be one of the attractions of that system. See Langbein, supra note 44 , at $826-29$.

112 See United States v. Bagley, 105 S. Ct. 3375, 3384 (1985), discussed infra at text accompanying notes 179-80; United States v. Agurs, 427 U.S. 97, 112-14 (1976) (impasing a materiality standard).

13s See Babcock, Fair Play: Evidence Favorable to an Accused" and Effective Assistance of Counsel, 34 STAN. L. REv. 1133, 1163 (1982). 
ognition of widespread imbalance (and particularly of frequent disputes between government and the poor), parity is required to sustain belief in adversarialism. Thus far, neither the Court nor the Congress has been willing to translate fully the rhetoric of adversarialism into actuality by mandating resource supplements.

The entry of impoverished litigants into the federal courts was not the only change that made problematic the process-based rights announced by the Court and the values of the Federal Rules. The kinds of cases filed by adequately equipped (and perhaps over-equipped) litigants have become increasingly complex. The more narrow confines of the nineteen-thirties paradigm liave been enlarged; the 1938 Rules encompass (and enable) more sprawling disputes. Instead of asking, Did Smith cause liarm to Jones (by breach of contract or by negligent action)? federal courts today address such questions as, Did a pattern of behavior engaged in by a corporation over a six-year period constitute employment discrimination? Did an industry breach its duty by failing to warn workers of hazardous conditions that developed over a decade? Did a group of entities and individuals conspire to limit competition within a market the boundaries of which are themselves difficult to describe?

Of course, many cases still involve relatively discrete retrospective evaluations of specific events. The federal courts liave thousands of so-called "ordinary" cases in which parties, lawyers, and judges invest hittle or no time. Approximately half the cases in federal court involve little or no discovery, ${ }^{114}$ and the overwhelming majority of disputes are withdrawn, settled, or decided before trial. ${ }^{115}$ Further, complex cases are by no means a new plenome-

11 See P. Connoluy, E. Holleman \& M. Kuhlman, Judicial Controls and the Crvil Litigative Process: Discovery 28 (1978) (approximately 52\% of the surveyed cases had no recorded discovery requests; $95.1 \%$ had 10 or fewer requests); Trubek, Sarat, Felstiner, Kritzer \& Grossman, The Costs of Ordinary Litigation, 31 UCLA L. Rev. 72, 90 (1983) (reporting no evidence of discovery in half the studied cases) [hereinafter cited as Trubek]; Brooklyn Law School, Discovery Study Status Report 5 (Sept. 1985) (on file with The University of Chicago Law Review) (of 52 Eastern District of New York cases in original sample, only half involved any discovery at all); cf. Speck, The Use of Discovery in United States District Courts, 60 YALE LJ. 1132, 1134 (1951) (concluding that discovery was "popular" on the basis of finding that discovery rules were used in over $25 \%$ of the cases).

11 See 1984 Administrative Office REPORT, suprá note 6, at 280 (only about 5\% of cases filed are tried); see also Trubek et al., supra note 114, at 86-87; cf. ALI Crvil CASEs, supra note 61 , at 74 (1934 study reporting that only $9.2 \%$ of the liquor cases and $12.4 \%$ of the non-liquor cases in a three-year period ending June 30,1930 went to trial).

Despite the superficial inpression that settlement rates have increased, historical comparisons of the rates are not possible on the basis of these data. Before the 1938 Federal Rules, some cases were commenced and concluded without the filing of any documents with 
non; the federal courts have long been engaged in dealing with multi-party, multi-issue disputes, such as bankruptcy proceedings. ${ }^{118}$ But there appears to have been a shift in the prevalence and visibility of complicated cases; we hear and know a good deal more about the complex side of the federal docket, and signs of distress about that side are evident. The pretrial process in these cases can be extensive and burdensome, ${ }^{117}$ and in the five percent of the cases tried, the trials take longer than they had in the past. ${ }^{118}$

Some of the changes in perception and reality must be attributed to the Federal Rules themselves, which enable both complexity and visibility. The 1938 Rules deliberately liberalized joinder practice; as the drafters discuss it, the idea was to permit a complete and thorough airing of a dispute and then to conclude it once and for all.119 But the perceptions of the boundaries of a dispute have themselves changed with that liberalization and with the merger of law and equity; the number of claims and parties that can fall within the Rules has impressed some with the need to advocate retrenchment. Further, the 1966 amendments to the Federal Rules worked major changes in both group litigation and

a court, see infra note 121 and accompanying text. As a consequence, we cannot know what percentage of all the disputes we would count as "cases" today were settled or withdrawn in the 1930s. For analysis of two rural counties' dockets that suggests no decline in trial rates over time, see Daniels, Continuity and Change in Patterns of Case Handling: A Case Study of Two Rural Counties, 19 L. \& Soc'y Rev. 381, 417 (1985).

118 See Eisenberg \& Yeazell, The Ordinary and the Extraordinary in Institutional Litigation, 93 HARv. L. REv. 465, 485-86 (1980).

${ }_{117}$ See, for example, the description of "the discovery travail" in In re Professional Hockey Antitrust Litigation, 63 F.R.D. 641, 643 (E.D. Pa. 1974) (dismissing suit with prejudice for failure to answer interrogatories), rev'd, 531 F.2d 1188 (3d Cir.) (rejecting dismissal sanction), rev'd sub nom. National Hockey League v. Metropolitan Hockey Club, 427 U.S. 639 (1976) (per curiam) (holding that dismissal was not an abuse of discretion). See generally Rosenberg \& King, Curbing Discovery Abuse in Civil Litigation: Enough is Enough, 1981 B.Y.U. L. REv. 579.

${ }_{118}$ In $1945,59.1 \%$ of the civil trials (both jury and bench) were completed in one day or less, $9.9 \%$ in 4 to 9 days, and $0.8 \%$ in 10 or more days. Anministrative Orfice of the United States Coutrs, Annual Report of the Director 100 (1945) [hereinafter cited as 1945 ADMINISTRATIVE OfFICE REPoRT]. In 1984, $46 \%$ of the civil trials were completed in one day or less, $19 \%$ in 4 to 9 days, and $3 \%$ in more than 10 days. 1984 Anministrative Orfice REPoRT, supra note 6, at 302 (extrapolated). Further, because during the same period the percentages of civil cases tried decreased from $13.5 \%$ in 1945 to $5 \%$ in 1984, the cumulative impression of the prevalance of longer trials has been enhanced. See 1945 ADMINISTRATIVE Orfice Report, supra, at 49 (excluding cases brought by Office of Price Administration) and 1984 Administrative Oprice Report, supra note 6, at 152. See Appendix B.

119 See Dobie, The Federal Rules of Civil Procedure, 25 VA. L. REv. 261, 267-68, 27074,283 (1939). For discussion of the views underlying the work in this period, see R. Bone's forthcoming article on the right, interests, and functional approaches of the rulemakers. Conversation with R. Bone (Spring 1986). 
third-party practice. The revision of the class action rule has enabled diverse sets of individuals to present themselves as groups to the federal courts and has prompted extensive consideration of when representative litigation is permissible. ${ }^{120}$

The Rules also have done much to redefine the interdependent roles of judges and attorneys. Before 1938, some localities apparently operated on the "hip pocket" system. Lawsuits "commenced" by the service of the complaint upon one's opponent. No documents were filed with the court until and unless some request was made to the court. ${ }^{121}$ In contrast, the 1938 Rules required that every lawsuit be "commenced" by the filing of a complaint with the court;; $;^{122}$ as a consequence, all pretrial activities must now occur under the umbrella of the court. Of course, in 1938 as today, many cases were terminated by voluntary agreement or by withdrawal. ${ }^{123}$ But by requiring the filing of the case and then by creating a "revolutionary" (as one of the drafters termed it) system of pretrial rights-to wit, discovery ${ }^{124}$ - the 1938 Rules enabled the development of a new set of activities and new conditions for the interaction of judge and lawyer. With the new procedural opportunities came a new set of lawyers, "litigators," who did their work (motions, deposition and interrogatory practice) during the pretrial process and who were to be distinguished from "trial lawyers," who actually conducted trials. ${ }^{125}$ In short, the 1938 Rules enabled us to understand what was known but not fully appreciated-that in most cases, the pretrial was all there was. In addition, the 1938 Rules enabled us to become aware of a host of attorneys' adversarial practices not previously within ready view of either judges or the public. ${ }^{126}$ Coupled with the shift from a master calendar to an

${ }^{120}$ See Yeazell, From Group Litigation to Class Action, Part II: Interest, Class, and Representation, 27 UCLA L. REv. 1067, 1107-20 (1980) (discussing Rule 23's confusion about when consent by the members of the class is required).

${ }^{121}$ The drafters considered but rejected the "hip pocket" system. See 2 J. Moore, J. Lucas, H. Fink \& C. Thompson, Moore's Federal. Practice II 3.03, at 3-12 (2d ed. 1985); I P. Edmunds, supra note 9, at 113-14. For a defense of that system, see Advisory Committee of Western District of New York, Rules of Procedure for District Courts, 9 N.Y. ST. B.A. BuLL. 268, 268 (1937) ("An action should be commenced by the simple issuance of a summons by the plaintiff or his attorney, and its service, without the necessity of filing a complaint. . . . [S]ervice of a summons [by itself] often brings about the settlement of a just claim.").

${ }^{122}$ Fed. R. Crv. P. 3. Rule 3 "does not affect [the tolling of] state statutes of limitations." Walker v. Armco Steel Corp., 446 U.S. 740, 751 (1980).

12s See supra note 115.

124 Dobie, supra note 119, at 275.

${ }^{125}$ Levy, Discovery-Use, and Abuse, Myth and Reality, 17 Forum 465, 470 (1981).

${ }^{128}$ Some of the contemporary writers seemed to think that discovery would be a vehi- 
individual calendar system ${ }^{127}$ and with fee-shifting statutes regulated by judges, ${ }^{128}$ the Rule changes permitted federal judges to become familiar with the practices of specific lawyers in particular cases.

Much of what judges (and to a lesser extent, the public) have seen during the pretrial period has led to substantial consternation. ${ }^{129}$ The increased visibility of adversarial behavior has revealed practices that make faith in its output problematic. First, judges have a heightened awareness of the uneven quality of attorneys; one motivation for managerial judging is a concern that, without judicial "guidance," attorneys may grievously disserve their clients" interests. A second concern comes under the code word "abuse"; the perception is that, by demanding too much or providing too little, attorneys waste the resources of clients and of the courts. ${ }^{130}$ Third, there is a growing awareness of the "big

cle for diminishing inappropriate adversarial activity. See Holtzoff, supra note 87, at 205 (the objectives of the new federal rules include the "elimination of the 'sporting theory' of justice").

${ }^{127}$ The influence of the individual calendar system has been profound, for it has linked judges to their caseloads and has thus created different understandings of what "good" judges accomplish. See Mauren Solomon, Casbrlow Management in the Trial Court 9 (1973) (suggesting that the calendar system creates a competitive atmosphere that motivates active case management); Chief Judge Motley Describes Court, Career; Reflects on National Impact of Landmark Cases, THIRD BRANCH, Dec. 1985, at 1, 6 [heremafter cited as Motley Interview] ("[T]he single-judge calendar system is the greatest invention since the wheel . . . . [H] aving an individual calendar system is the incentive for everybody to keep working so that he is not the last man on the totem pole.").

${ }^{228}$ Fee applications have told us a good deal about attorneys' practices. See Report of the Third Circuit Task Force, Court Awarded Attorney Fees, 108 F.R.D. 237 (1985); Leubsdorf, Toward a History of the American Rule on Attorney Fee Recovery, 47 LAw \& CoNTEMP. ProBs. 9, 31-36 (1984) (discussing the impact of fee shifting).

${ }^{120}$ See, e.g., Roadway Express, Inc. v. Piper, 447 U.S. 752, 754-57 \& n.4 (1980) (describing conduct leading to decision to tax attorney's fees directly against counsel); Miller, The Adversary System: Dinosaur or Phoenix, 69 Mins. L. Rev. 1, 8-16 (1984); Note, The Emerging Deterrence Orientation in the Imposition of Discovery Sanctions, 91 Harv. L. REv. 1033, 1044-45 (1978).

${ }^{180}$ Documenting the frequency (rather than the visibility) of attorney misbehavior is very difficult. See Brazil, Views from the Front Lines: Observations by Chicago Lawyers about the System of Civil Discovery, 1980 AM. B. Found. Reskarch J. 217, 229 (attorneys and judges indicate that discovery problems are prevalent only in the "subworld" of larger cases).

Some of the distress about attorney behavior has worked its way into the Federal Rules. See, for example, the 1980 amendment to Rule 34, which governs the production of documents. The rule was amended to require that documents be presented in the order in which they are kept or in the order requested by the opposing counsel. The following explanation is dryly offered: "The Committee is advised that, "It is apparently not rare for parties dehberately to mix critical documents with others in the lopes of obscuring significance." "FED. R. Civ. P. 34, Note to 1980 Amendment (quoting Section of Litigation of the American Bar Association, Report of the Special Committee for the Study of Discovery Abuse 22 (1977)). 
spenders," clients with seemingly unbounded resources who can purchase attorney services to fuel unending battles. Finally, because of fee submissions, the precise dollar translations of all attorney behavior (good and bad) can now be made.

Are lawyers today qualitatively different from those who practiced fifty years ago? Although there was a tendency to attribute such malfeasance to "New York" lawyers, the drafters of the Federal Rules were aware of "sharp" practices and attorney ineptitude. ${ }^{131}$ But the current literature appears to contain an unending number of complaints against lawyers. Today's rule drafters seem to have more reservations about the utility of adversarial modes of interaction than did their counterparts fifty years ago. Explanations for this cliange in the rhetoric are varied. Perhaps "gentlemanly lawyers" did in fact behave differently fifty years ago than do their contemporary counterparts. ${ }^{132}$ Perhaps the behavior of attorneys has remained relatively consistent, but the individuals harmed by attorney malfeasance liave changed. Then, as now, inept or dishonest lawyers harmed clients a good deal. Only occasionally, however, was attorney misbehavior a problem for a judge, who had to hear a poorly prepared motion or supervise a badly orchestrated trial. But today, as cases liave become more complex and pretrial preparation has become court-centered, attorney misbeliavior is likely to be a problem for judges, who depend upon attorneys to simplify and to clarify issues. When attorneys fail, judges suffer. Further, judges who perceive themselves as overworked may become impatient with too many nuances and may express dismay at what is, in fact, good lawyering. In sliort, today the judge's ox is sometimes gored by attorney behavior; as a consequence, many judges actively attempt to supervise attorneys.

Finally, during the past fifty years, a host of new, quasi-adjudicatory bodies-agencies-have flourished and now dot the landscape of dispute resolution. Virtually since the inception of the United States, federal courts have not been the exclusive venue for

More recent amendments to Rule 11 (governing certification of documents) and to Rule 26 (concerning discovery) also acknowledge the potential for attorney overreaching and permit judges to impose sanctions directly on attorneys. See Order Amending Federal Rules of Civil Procedure, 461 U.S. 1097 (1983).

${ }_{131}$ Clark, The Bar, supra note 26, at 23; see also Hickman v. Taylor, 329 U.S. 495, 511 (1947) (work product protection necessary to insure against "sharp practices"); E. MoRGAN, supra note 82 , at 32 ("The success or failure of any procedural device depends upon the judges and lawyers . . . using it.").

${ }_{132}$ Cf. Genego, Risky Business-The Hazards of Being a Private Criminal Defense Lawyer, 1 CRIM. JUST. 2, 39-40 (1986) (survey of the increased use of harassing tactics by federal prosecutors). 
federal adjudication, ${ }^{133}$ but their claim of uniqueness has diminished over the past five decades. Agencies now preside over a vast proportion of the factfinding within the federal system. ${ }^{134}$ When the drafters of the 1938 Federal Rules worked, there seemed to be an unstated assumption that there was an arena of court-based activity that could be readily delineated. Today, the line that they may have assumed has become quite blurred-in both directions. Federal courts have required agencies to act a good deal more hike courts, to provide "due process" by conducting their business much in the manner of a court. Moreover, federal courts have themselves become more dependent upon non-Article III actors, such as bankruptcy judges and magistrates, to dispose of much of the federal courts' own docket. ${ }^{135}$ The Supreme Court's recent difficulties in articulating what powers Congress cannot, constitutionally, bestow upon non-Article III actors bespeak the complexity of delineating judge from non-judge. ${ }^{136}$

To summarize, in the past fifty (and particularly in the past twenty) years, the docket of the federal courts has changed in several significant ways. First and foremost in the minds of many jurists, ${ }^{137}$ there are a lot more cases to decide. ${ }^{138}$ Second, some of

18: See American Ins. Co. v. Canter, 26 U.S. (1 Pet.) 511, 546 (1828) (territorial courts permissible). See generally Resnik, The Mythic Meaning of Article III Courts, 56 U. CoLo. L. REv. 581 (1983) (discussing the growth of non-Article III adjudication); Comment, The Boundaries of Article III: Delegation of Final Decisionmaking Authority to Magistrates, 52 U. CHL L. REv. 1032, 1038-48 (1985) (discussing the permissible exercises of power by nonArticle III actors).

13. As of June 1984, Article III courts had 250,962 civil actions pending. 1984 ADminisTRATION Office REPORT, supra note 6, at 124. By comparison, the Social Security Adininistration alone made 337,459 dispositions. Social Security Administration, U.S. DEp't of Health and Human Services, Operational Rzport of the Office of Hearings and ApPEALS 26 (Sept. 30, 1984).

${ }^{285}$ For a discussion of the delegation of work to magistrates, see Carroll SERon, The Roles of Magistrates: Nine Case Studies (1985).

2se See Northern Pipehine Constr. Co. v. Marathon Pipe Line Co., 458 U.S. 50 (1982); Resnik, supra note 133, at 597-603 (1985).

257 Discussions of statistics and dispositions dominate much of the federal judiciary's commentary. See, e.g., Motley Interview, supra note 127, at 6 (major shift in last twenty years is the increase in litigation).

12: In 1945, the number of civil cases commenced was 60,965. 1945 ADMinistrative OFFICE REPORT, supra note 118, at 82 . In 1984, the number of civil cases commenced was 261,485. 1984 Administrative OfFice REPORT, supra note 6, at 249. Of course, the number of judgeships has increased. But the number of filings per judge has also increased. In 1945 there were approximately 336 civil filings per judge-a figure derived from taking the number of civil cases commenced in that year, see 1945 ADMINISTRative Office REPort, supra note 118 , at 83 , and dividing by the 181 district court judges active at that time, see $61 \mathrm{~F}$. Supp. vii, vii-xiv (1945) (listing of judges). In 1984, there were 508 civil filings per judge. 1984 Administrative OFfice RRPORT, supra note 6, at 129 (filings per authorized judgeship). Note that these data do not decide the "hitigation explosion" question; information on filing 
those cases involve disputes between the very powerful (often but not exclusively the government) and the very poor. Third, new federal legislation has served as the basis for complex cases in which the underlying disputes may involve multiple incidents and require the production of numerous witnesses and thousands of documents. ${ }^{139}$ Fourth, an important set of cases involves group litigation, in which representatives seek recognition to pursue the rights of individuals not physically before the court and sometimes not even aware of the pendency of the lawsuit. Fifth, in those cases in which court-based activity actually occurs, the litigation is sometimes protracted and complex, and the opportunities for adversarialism in the pretrial process or at trial are multiplied. Sixth, because that adversarialism occurs under the umbrella of the courtbased discovery rights established by the Federal Rules of Civil Procedure and in the context of an individual calendar system and fee-shifting statutes, judges see a good deal of aggressive or inept attorneys. Finally, many other institutions within the society have been obligated to perform court-like functions in a court-like manner, and the growing use of such alternatives raises questions about the appropriate domain of the federal courts. ${ }^{140}$

\section{FaIIING FaIth}

These changes have not gone unnoticed by today's drafters of the Federal Rules. Several inroads have been made in some of the decisions of the 1938 group. First, the premise of trans-substantive rules has been silently undermined-de jure and de facto. At a formal level, the Court has promulgated special rules for the litigation of prisoners' habeas corpus cases. ${ }^{141}$ In addition, the recently re-

rates as contrasted with population size is not included in the Administrative Office's data.

${ }^{130}$ Such cases also make problematic the delineation between questions of fact and questions of law. Thus far, the Supreme Court has not been sensitive to these complexities. See, e.g., Pullman-Standard v. Swint, 456 U.S. 273, 285-90 (1982) (treating discriminatory motive as a question of "fact" when the Court delineated the proper scope of appellate review); see also Resnik, Tiers, 57 S. CAL. L. REv. 837, 998-1005 (1984) (critiquing PullmanStandard).

110 The question of what is "court-like" is more complex than this sentence indicates. It may well be that our current understanding of "adjudication" will not last the century, and that subsequent commentators will understand a different configuration of activities as belonging to courts. See Schwartz, The Other Things That Courts Do, 28 UCLA L. REv. 438 (1981).

111 Order Promulgating Rules Governing 28 U.S.C. $\S 2254$ Cases in the U.S. District Courts and Rules Governing 28 U.S.C \& 2255 Proceedings for the U.S. District Courts, 425 U.S. 1169 (1976). Some of these rules were modified by Congress. See Pub. L. No. 94-426, $\S \S 1-2,90$ Stat. 1334 (1976); Pub. L. No. 94-577, § 2, 90 Stat. 2730 (1976). See generally Clinton, Rule 9 of the Federal Habeas Corpus Rules: A Case Study on the Need for Reform 
vised Manual for Complex Litigation has created a distinct set of rules for cases with multiple parties or complex issues. ${ }^{142}$ At an informal level, the emergence of managerial judging ${ }^{143}$ and the approval of that phenomenon in the 1983 amendments to Rule 16 (governing pretrial procedures) 144 $^{14}$ exemplify ad hoc efforts to tailor rules to individual cases. As other papers in this symposium detail, judges and lawyers across the country are busily creating new procedures for different kinds of cases. ${ }^{145}$ The zeal of many of the advocates of such efforts ${ }^{146}$ underscores their judgment that transsubstantive rules are often inadequate.

Second, the silence of the original Rules about appropriate attorney behavior has been modified to some extent by the expansion of judicial authority to impose sanctions upon attorneys. The 1983 amendments to Rules 11 and 26, and the emerging commentary and case law concerning those amendments, ${ }^{147}$ evidence a new willingness by judges to describe the permissible scope of adversarialism $^{148}$ and to curtail unbridled aggression. Further, judges have been forced to contemplate the validity of the assumption that the attorney and client are a "moral unit."149 Attorney sanc-

of the Rules Enabling Acts, 63 Iowa L. Rev. 15 (1977).

142 Manual for Complex Litigation, Second (1985). In addition to discussing generally applicable techniques, the Manual suggests methods for handling particular types of cases: antitrust ( $\$ 33.1$ ), coinplex tort cases ( $\$ 33.2$ ), securities litigation ( $\$ 33.3$ ), takeover litigation ( $\$ 33.4$ ), employment discrimination litigation ( $\$ 33.5$ ), and patent litigation (§33.6).

143 See Resnik, supra note 17, at 391-400.

14 Under Rule 16 of the Federal Rules, the judge is to approve a schedule for pretrial events and to discuss settlement when appropriate.

${ }^{145}$ See Brazil, Special Masters in Complex Cases: Extending the Judiciary or Reshaping Adjudication?, 53 U. CHI. L. REv. 394 (1986); Lieberman \& Henry, Lessons from ADR, 53 U. ChI. L. Rev. 424 (1986); McGovern, Toward a Functional Approach For Managing Complex Litigation, 53 U. CHL. L. Rev. 440 (1986); Posner, The Summary Jury Trial and Other Methods of Alternative Dispute Resolution: Some Cautionary Observations, 53 U. CHI. L. REv. 366 (1986).

${ }^{14}$ See Lambros, The Summary Jury Trial and Other Alternative Methods of Dispute Resolution, 103 F.R.D. 461 (1984); Lambros \& Shunk, The Summary Jury Trial, 29 CLEv. ST. L. REv. 43 (1980).

${ }_{147}$ See, e.g., Scliwarzer, Sanctions under the New Federal Rule 11-A Closer Look, 104 F.R.D. 181, 183-84 (1985); Strasser, Sanctions: A Sword is Sharpened, Nat'l Law J., Nov. 11, 1985, at 1, col. 2 (law firms across the country report inposition by judges of large monetary sanctions).

14s See U.S. District Court for the Eastern District of New York, Standing Orders of the Court on Effective Discovery in Civil Cases, 1984, in 2 Local Court Rules, supra note 4; Revised Report of the Special Committee on Effective Discovery in Civil Cases for the Eastern District of New York (1983) (on file with The University of Chicago Law Review) (effort by Chief Judge Jack Weinstein and an advisory committee to delineate appropriate interaction during discovery).

149 Cover \& Aleinikoff, Dialectical Federalism: Habeas Corpus and the Court, 86 Yale 


\section{tions (in addition to or instead of client sanctions) are now in vogue. ${ }^{180}$}

Third, the quiet reference in the 1983 amendments to the propriety of court involvement in settlement efforts, ${ }^{151}$ coupled with the ongoing discussion about fee-shifting as a sanction for failure to settle, ${ }^{162}$ indicate a new emphasis on settlement. Many federal judges have begun to perceive themselves as being in the business of settlement as much as (sometimes more than) in the business of adjudication. ${ }^{163}$ Other actors have entered the marketplace of dispute resolution and are now hawking their wares to federal judges and to the academic community. ${ }^{164}$ Many of these enterprises advertise themselves as facilitating settlement-not adjudication ${ }^{155}$ _and aim to "educate" the federal judiciary on the advisability of shifting dispute resolution to "alternative" spheres. ${ }^{156}$ Federal judges, not so clear on the definition of what they (in con-

L.J. 1035, 1042 (1977).

${ }_{150}$ See, e.g., Pub. L. No. 96-349, § 3, 94 Stat. 1156 (1980) (amending 28 U.S.C. § 1927) (making counsel "personally" liable for excess costs, including attorney's fees, due to unreasonable and vexatious litigation); FED. R. Crv. P. 11 (sanctions for signing papers without requisite good faith basis for allegations or arguments); FED. R. Crv. P. 26 (sanctions for discovery activities). See generally Burbank, Sanctions in the Proposed Amendments to the Federal Rules of Civil Procedure: Some Questions About Power, 11 Horstra L. Rev. 997 (1983).

${ }_{101}$ FED. R. Crv. P. 16(a) now authorizes the district court to require a conference for, among otler things, "facilitating the settlement of the case."

${ }^{152}$ For descriptions of recent proposals to amend Rule 68 to autlorize sanctions for "unreasonably" refusing to settle, see Marek v. Cliesny, 105 S. Ct. 3012, 3033-34 \& nn.56-58 (1985) (Brennan, J., dissenting); Comm. on Rules of Practice and Procedure of the Judicial Conference of the U.S., Preliminary Draft of Proposed Amendments to the Federal Rules of Civil Procedure, 98 F.R.D 339, 361-67 (1983) (proposed rule and committee note); Comm. on Rules of Practice and Procedure of the Judicial Conference of the U.S., Proposed Court Rules, 102 F.R.D. 407, 432-37 (1984) [liereinafter cited as Proposed Court Rules] (later version of proposed rule and committoe note). For discussion of the problems raised by Marek, see Macklin, Promoting Settlement, Forgoing the Facts, 14 N.Y.U. Rev. L. \& Soc. Change 1201 (1986).

${ }^{153}$ But cf. Trends in Federal Law and Procedure, 5 F.R.D. 361, 364 (1946) (discussion by Judge Moskovitz: "[J]udges conducting pretrial conferences sliould be careful not to give the impression of advocating that the attorneys settle the matter . . . . [A] suggestion to the attorneys that they discuss the possibilities of settlement should be the limit of impetus from the court.").

${ }^{164}$ See, e.g., The Mini-Trial Workbook (Center for Public Resources 1985); ADR Manual, supra note 13; Gordon, You, Too, Can Stay Out of Court, L. A. Daily J., Sept. 20, 1985, at 4 (discussing EnDispute).

${ }_{185}$ E.g., Green, Growth of the Mini-Trial, Litigation, Fall 1982, at 12 (mimi-trial as a "powerful new technique for setthing complex civil cases").

${ }^{158}$ See Peckham, A Judicial Response to the Cost of Litigation: Case Management, Two-Stage Discovery Planning and Alternative Dispute Resolution, 37 RUTGers L. Rev. $235,267-77 \& \mathrm{n} .93$ (1985) (description of the educational efforts of private groups and of the alternatives available). 
trast to other dispute resolution centers) do, have evidenced a willingness to incorporate new responses to the lawsints pending before them.

These changes might be understood as evolutionary adaptations of the 1938 Rules to contemporary problems. ${ }^{167}$ Further, our history is replete with periodic, intense complaints about the "administration of justice," and the nineteen-eighties might be one such moment. Our perceptions of its import may be distorted. But the recitation of the changes does not quite capture the tenor of the discussions of the last decade about federal procedure; the Rule revisions and the current proposals reflect deep dissatisfaction with some of the beliefs embodied in the 1938 draft. The dominant claim today is that the framework has provided too many opportunities for exploitation and manipulation and too little guidance for tlie untutored. Many of the calls for reform seek to contract the occasions upon whicli procedure could be used-either by shortening the time between filing and disposition or by eliminating some of the procedural options. A justification often offered is, essentially, that "less is more," tliat fewer procedural opportunities will beget more dispositions and that more dispositions are inlerently desirable. ${ }^{158}$ The utility of adjudication is now implicitly questioned.

I believe that the pressures to produce outcomes, coupled with first-hand experiences of seemingly illogical results rendered after extensive adversarial parrying by apparently unbridled attorneys, liave generated the emerging cynicism. If outcoines after trial or otlier forms of adjudication cannot, systematically and in the aggregate, be demonstrated (or at least felt) to be better than outcomes produced with little or no process, if attorney misbehavior and incompetence are widespread, if the adversarial model is applied in settings which render it farcical, wlyy insist upon formal procedure? Why not just produce inexpensive outcomes by arriving at settlements as quickly as possible? Why not give courts a large arsenal by which to urge, even to force, settlements? Why search for legitimacy in formal procedure? As federal judges selfconsciously slift roles from adjudicator to case-manager to settler,

${ }^{157}$ See Elliott, Managerial Judging and the Evolution of Procedure, 53 U. CHL. L. REv. 306 (1986). But see Subrin, supra note 31, at 1649-51 (arguing that judicial management deviates from the four central presumptions of the drafters of the 1938 Rules).

183 See Newman, Rethinking Fairness: Perspectives on the Litigation Process, 94 Yals L.J. 1643, 1652 (1985) (arguing that we can no longer afford to "retain any procedure that could conceivably increase the hikelihood of a fair result" because procedure leads to delay and the "consequent loss of fairness to all others affected by the litigation process."). 
as judges call for the increased use of summary judgment ${ }^{159}$ and for other quick solutions, judges demonstrate their own sense of the marginal utility-and perhaps of the futility-of full-blown adjudication.

There are many examples of this failing faith. On the civil side, recent Supreme Court cases display the majority's willingness to press for dispositions, no matter what the procedure. One example is the veterans benefits case, Walters $v$. National Association of Radiation Survivors. ${ }^{160}$ In Walters, a federal district court had issued a prehminary injunction against the enforcement of a statute, dating from 1866, which prohibited attorneys representing veterans before the Veterans Administration from charging inore than ten dollars per case. ${ }^{161}$ Apparently, the fee had not functioned as a bar to representation by attorneys at the time of its enactment, but by the nineteen-eighties, the fee effectively precluded attorneys from appearing. ${ }^{162}$ While acknowledging the complexity of some of the cases in which representation was sought, the Court (by Justice Rehnquist) reversed the injunction and upheld the statute as constitutional against both first and fifth amendment challenges. ${ }^{163}$ The Court's hostility to lawyers and to the procedures they engender is palpable:

It is scarcely open to doubt that if claimants were permitted to retain compensated attorneys the day might come when it could be said that an attorney might indeed be necessary to present a claim properly in a system rendered more adversary and more complex by the very presence of lawyer representation. ${ }^{164}$

Simplicity and nonadversarial exchanges have enormous appeal, but it is difficult to find them in the interaction between veteran and bureaucracy. According to studies cited by the Court, the Vet-

${ }^{159}$ See, e.g., Schwarzer, supra note 30.

160105 S. Ct. 3180 (1985).

16138 U.S.C. § 3404(c)(2) (1983).

$162105 \mathrm{~S}$. Ct. at 3210 (Stevens, J., dissenting) ("[I]n terms of the average serviceman's base pay, a $\$ 10$ fee then was roughly the equivalent of a $\$ 580$ fee today.").

1es Id. at 3196-97.

106 Id. at 3192. This comment is reminiscent of an earlier remark by the Chief Justice that what "the juvenile court system needs is not more but less of the trappings of legal procedure and judicial formalism." In re Winship, 397 U.S. 358, 376 (1970) (Burger, C.J., dissenting) (opposing requirement of proof beyond a reasonable doubt in juvenile coinmitment proceedings). Of course, the Court is ambivalent towards lawyers. Cf. Zauderer v. Office of Disciphnary Counsel, 105 S. Ct. 2265, 2278 (1985) (White, J.) ("[W]e cannot endorse the proposition that a lawsuit, as such, is an evil."). 
erans Administration processed more than 800,000 claims a year-almost half of which were disallowed at the initial proceeding. ${ }^{165}$

A second case is Marek $v$. Chesny. ${ }^{168}$ The question in Marek was the relationship between the Civil Rights Attorneys' Fee Act of $1976^{187}$ and the breadth of the sanction provided in the 1938 Federal Rules for failure to settle. As interpreted previously by the Supreme Court, rule 68 provides that a plaintiff (but not a defendant) who refuses a timely, written settlement offer may be taxed "costs" from the date of the offer if a victory at trial is less than the offered settlement. ${ }^{168}$ At issue in Marek was the definition of the word "costs"; could "attorneys' fees," described in some federal legislation (including the Civil Rights Fee Act) as taxable "as part of the costs,"160 be a part of the "costs" referred to under rule 68 ? Could a defendant in a civil rights case no longer be liable for a victorious plaintiff's attorneys' fees incurred after a rule 68 offer when the plaintiff recovered a judgment less than the offer? Could such a reading be squared with the Civil Rights Fee Act, which provides a one-way shift from defendants to prevailing plaintiffs to encourage civil rights filings (understood as enforcing pubhic policy)? Writing for the majority, the Chief Justice (long a proponent of increased sanctions for failure to settle) answered in the affirmative. "To be sure, apphication of Rule 68 to include attorneys' fees ... will require plaintiffs to think very hard about whether continued litigation is worthwhile,"170 but "encourag[ing] settlements" is the point. ${ }^{171}$ The majority in Marek insisted that its reading of the rule was "neutral." But the rule operates in a world already full of social inequality. By definition, civil rights plaintiffs challenge state action; by implication, many of those cases involve plaintiffs with vastly fewer resources than defendants possess. The Court's reading ignored the complexity of the disparate impact that the increase in economic incentives to settle has upon hitigants with vastly divergent resources. ${ }^{172}$ Marek exemplifies the willing-

168105 S. Ct. at 3183.

166105 S. Ct. 3012 (1985).

16742 U.S.C. § 1988 (1982).

16s Delta Air Lines v. August, 450 U.S. 346, 352 (1981).

180 See, e.g., 42 U.S.C. $\$ 1988$ (1982), construed in Marek, 105 S. Ct. at 3015.

170105 S. Ct. at 3018.

171 Id.

${ }^{172}$ See Shavell, Suit, Settlement, and Trial: A Theoretical Analysis Under Alternative Methods for the Allocation of Legal Costs, 11 J. Legal Stud. 55, 63-69 (1982); Bone, Brennan, Chemerinsky, Curtis, Genego, Ragsdale \& Resnik, Comments on Proposals to Amend the Federal Rules of Civil Procedure, Submitted to the Advisory Colnmittee to tbe 
ness of jurists to increase the pressures upon litigants to bail out.

This past term, the focus shifted from client to lawyer. In $E v$ ans $v$. Jeff $D .,^{173}$ the Court again evidenced its ambivalence, if not hostility, towards trial as a method of decisionmaking. Like Marek, Evans addressed the question of the relationship between the Civil Rights Attorneys' Fee Act and a Federal Rule, this time 23(e), which prohibits the dismissal or compromise of class actions without court approval. In Evans, the Court permitted district court endorsements of settlements that were conditioned upon the waiver of fees by plaintiffs' lawyers; once again, the Court limited the impact of the Civil Rights Fee Act by enhancing "the attractiveness of settleinent." present civil rights plaintiffs in the hopes of recovering fees will now have to pause before making such investments. ${ }^{175}$ Presumably, the number of civil rights filings will be reduced, as will the already small percentage of cases tried.

On the criminal and administrative sides of the docket, parallel illustrations of the anti-adjudication posture are easily identified. Most criminal decisionmaking occurs through the settlement process-plea bargaining. Criticism of plea bargaining comes from prosecution, defense, and the judiciary; no one much likes the system but no one wants to pay for the alternative-adjudication. ${ }^{176}$ At any point in the criminal process, adjudication is resisted. Thus, when defense advocates seek to require factfinding to determine degrees of culpability at sentencing or parole, their efforts are rebuffed; there is great reluctance to require factfinding hearings or many of the other rights associated with adjudication. ${ }^{177}$ In-

Standing Committee of the Judicial Conference on Rules of Practice and Procedure in the United States Courts (1985) [hereinafter cited as USC Law Professors' Testimony] (on file with The University of Chicago Law Review).

173106 S. Ct. 1531 (1986).

174 Id. at 1540.

${ }^{178}$ Compare the approach of the Third Circuit in Prandini v. National Tea Co., 557 F.2d 1015, 1017 (1977) (banning simultaneous negotiations of the inerits and of attorneys' fees to minimize the conflicts between client and lawyer).

${ }^{170}$ See Alscbuler, Implementing the Criminal Defendant's Right to Trial: Alternatives to the Plea Bargaining System, 50 U. CHI. L. REv. 931, 955 (1983).

177 An example of this was Judge Weinstein's effort, rebuffed by the Second Circuit, to import evidentiary norms into the sentencing process. See United States v. Fatico, 441 F. Supp. 1285 (E.D.N.Y. 1977), rev'd, 579 F.2d 707 (2d Cir.), on remand, 458 F. Supp. 388 (E.D.N.Y. 1978), aff'd in part, 603 F.2d 1053 (2d Cir. 1979), cert. denied, 440 U.S. 1073 (1980); see also United States v. Napohtano, 761 F.2d 135, 138-39 (2d Cir. 1985) (permitting use of hearsay at sentencing hearing), cert. denied, 106 S. Ct. 129 (1985); United States v. Papajohn, 701 F.2d 760 (8th Cir. 1983) (trial judge has broad discretion in conduct of presentence hearing). 
stead, judges, parole examiners, and other government officials are left to rely upon hearsay comments made by prosecutors and found in agency files. These decisionmakers reach judgments based upon minimal standards of proof. Pressing for procedural formality undermines the economies of the disposition-oriented mode. ${ }^{178}$

Further, in the few criminal cases that are tried, the decisions reached have impressive durability; harmless error doctrine has grown and enforcement of criminal defendants' rights has diminished. The recent evisceration of the Brady $v$. Maryland requirement that prosecutors provide exculpatory evidence to defendants underscores the distance between the adjudicatory premises of the past decades and the current acceptance of a disposition-oriented system. In United States v. Bagley, defense counsel had specifically requested disclosures about whether witness-informants were paid by the government. ${ }^{179}$ The information was not provided; the defendant was convicted, and subsequently, via a Freedom of Information Act request, documents were obtained estabhishing the government contract with and payment of the informants. However, the Supreme Court declined to penalize the government for its refusal to respect its Brady commitments. ${ }^{180}$ Bagley is part of a larger picture of the curtailment of habeas corpus hitigation ${ }^{\mathbf{1 8 1}}$ and of the increased finality of first-tier decisions in non-criminal contexts as well. ${ }^{182}$ Once an outcome is obtamed, it has become increasingly difficult to revise it.

In the administrative and rulemaking contexts, the story is similar. Goldberg $v$. Kelly has been understood narrowly as the Court has praised the virtues of informality and has declimed to require more stylized adjudicatory encounters. ${ }^{183}$ What Goldberg

${ }^{178}$ In the federal system, sentences have typically been determined by judges who had not participated in the bargaining process. See Curtis, Federal Judicial Power, Parole Guidelines, and Sentence Reform, in 2 PrIsoners' RIghts Sourcebook, supra note 78, at 97-98. However, the recently-revised Federal Criminal Code will, when it,becomes effective, require judges to articulate reasons for sentences-obliging some form of judicial factfinding as a predicate to sentencing. See Comprehensive Crime Control Act of 1984, Pub. L. No. 98473 , tit. 2,98 Stat. 1837 (to be codified at 18 U.S.C. $\$ \S 3351-3358$ ). If this quasi-adjudication requirement is enforced, an enormous number of factfinding hearings would be required.

$170105 \mathrm{~S}$. Ct. 3375 (1985).

${ }^{180}$ See Babcock, supra note 113, at 1148-50.

183 See Resnik, supra note 139, at 874-962.

${ }_{182}$ See id. at 982-1004.

${ }^{188}$ See, e.g., Parham v. J.R., 442 U.S. 584, 607-13 (1979) (no formal procedures for commitment of child to state mental hospital); Mathews v. Eldridge, 424 U.S. $319,347-49$ (1976) (no oral pretermination hearing required for disability benefits); see also Masbaw, The Supreme Court's Due Process Calculus for Administrative Adjudication in Mathews v. Eldridge: Three Factors in Search of a Theory of Value, 44 U. CHr. L. Rev. 28 (1976). 
described in 1969 (perhaps in an advocacy mode) as "rudimentary due process"184 has now become the high water mark. Further, Supreme Court pronouncements in cases are not the only evidence of this antipathy to adjudicatory procedure. Recent rulemaking efforts-including proposals to amend Rule 68 to give it more "bite"-demonstrate the same impulses, ${ }^{185}$ as do the speeches and writings of federal judges, advocating less adjudication and more reliance upon alternatives. ${ }^{188}$

Two popular approaches-managerial judging and alternative dispute resolution-further illustrate the declining interest in adjudication. ${ }^{187}$ Managerial judging employs the trial judge as a case manager, moving a lawsuit from filing to disposition. While proponents of managerial judging make occasional (and as yet undocumented) claims that their activity produces better outcomes, the primary justification advanced is economy. Managerial judging is promoted as providing quicker, less expensive dispositions. ${ }^{188}$ Elsewhere, I have indicated my skepticisin about the proposition; ${ }^{188}$ the relevance of the phenomenon here is that the rhetoric of judging has shifted from discussions of the difficulties of adjudication to the need to increase case dispositions. ${ }^{190}$ Moreover, in the last few

184 Goldberg, 397 U.S. at 267.

${ }^{185}$ See Marek v. Chesny, 105 S. Ct. 3012, 3032-35 (1985) (Brennan, J., dissenting) (describing proposed amendments); Simon, Rule 68 at the Crossroads: The Relationship Between Offers of Judgment and Statutory Attorney's Fees, 53 U. Cn. L. REv. 889, 893-94 (1984) (proposing expansion of rule 68). In 1986, the Advisory Committee voted to table the proposal indefinitely. Letter from Judge Frank M. Johnson, Jr., Chair of the Advisory Committee, to Professor Laura Macklin (May 19, 1986) (on file with The University of Chicago Law Review).

${ }^{186}$ See, e.g., Lambros, supra note 146, at 476-77; Newman, supra note 158, at 1644-45 (1985); Peckham, supra note 156, at 277.

${ }_{187}$ These two approaches may not be two discrete phenomena but rather two variations on a single theme.

${ }^{188}$ See FED. R. Crv. P. 16, Advisory Committee Commentary to the 1983 Amendment [hereinafter cited as Rule 16 Commentary] ("Empirical studies reveal that when a trial judge intervenes personally at an early stage to assume judicial control over a case . . . the case is disposed of . . . with less cost and delay than when the parties are left to their own devices."); see also Flanders, Blind Umpires-A Response to Professor Resnik, 35 HAST. L.J. 505, 516-19 (1984) (providing data on disposition time); Peckham, supra note 156, at 277 ("case management . . . can contain litigation costs"). For an attempt to link "economy" and "fairness," see Newman, supra note 158, at 1652.

${ }_{189}$ See Resnik, supra note 17, at 417-31; see also Menkel-Meadow, For and Against Settlement: Uses and Abuses of the Mandatory Settlement Conference, 33 UCLA L. REv. 485, 493-98 (1985) (data available do not support efficiency argument for judicial settlement conferences).

190 For examples of earlier, loftier treatments of the judicial role, see Wyzanski, $A$ Trial Judge's Freedom and Responsibility, 65 HaRv. L. REv. 1281, 1304 (1952), Yankwich, The Art of Being a Judge, 105 U. PA. L. REv. 374, 388 (1957), and Devitt, Ten Commandments for the New Judge, 47 A.B.A. J. 1175 (1961). 
years, managerial judges have focused increasingly upon judicial involvement in settlement. ${ }^{191}$ The attention paid to the judicial settlement role clarifies one aspect of the impetus for increased court control: the goals include constraining adversarial activity so as to conclude cases without adjudication. The volume of case dispositions (rather than the substantive law in general, the merits of a particular case, improved techniques for factfinding) has become the be-all and end-all of many within the federal judiciary.

The attention paid to alternative dispute resolution (known in the trade as $\mathrm{ADR}$ ) is the other innovation demonstrating diminished interest in adjudication. ${ }^{192}$ Ours is not the first generation to be intrigued by responses to disputes other than adjudication by judges. In colonial New York, there was talk of the use of arbitrators; ${ }^{193}$ in the early nineteen-thirties, some judges urged their colleagues to consider the virtues of "conciliation";194 and during the twenties and thirties, agency decisionmaking and arbitration were seen as important alternatives to the expensive and difficult course of hitigation. ${ }^{198}$ The current revival of interest in ADR comes, however, with a slight twist. In the past, while arbitration agreements ${ }^{196}$ and agency decisions were enforceable in court, ${ }^{197}$ the "alternative" activity itself occurred separate from the courthouse. ${ }^{188}$

101 See D. Marie Provine, Settlement Strategres for Federal District Judges (1986); Peckham, supra note 156, at 269-77; Resnik, supra note 17, at 421; see also Elliott, supra note 157, at 323-26; Galanter, “. . . A Settlement Judge, not a Trial Judge": Judicial Mediation in the United States, 12 J.L. \& Soc'y 1, 2-3 (1985); Menkel-Meadow, supra note 189 , at $486-90$.

${ }^{102}$ See generally Alternative Dispute Resolution and the Courts, 69 JUDICATURE 251 (1986); Edwards, Alternative Dispute Resolution: Panacea or Anathema?, 99 HaRv. L. REv. 668 (1986).

${ }^{193}$ Henry Scott, The Courts of the State of New York: Their History, DevelopMENT AND JURJSDICTION 43-44 (1909).

184 E.g., Randall, Conciliation as a Function of the Judge, 18 Ky. L.J. 330, 340 (1930).

${ }^{106}$ See Wilko v. Swan, 346 U.S. 427, 430-32 (1953) (arbitration); WaLTER DoDd, ADMINIstration of WoRkMEN's CoMpensation 100-02 (1936); Comment, Judicial Review of Administrative Findings-Crowell v. Benson, 41 YALE L.J. 1037 (1932) (arguing for limited court review).

196 United States Arbitration Act of 1925, 9 U.S.C. $\$ 4$ (1982). For applications of the Act, see Mitsubishi Motors Corp. v. Soler Chrysler-Plymoutl, Inc. 105 S. Ct. 3346, 3355 (1985); Moses H. Cone Memorial Hosp. v. Mercury Constr. Corp., 460 U.S. 1, 29 (1983); see also Allison, Arbitration Agreements and Antitrust Claims: The Need for Enhanced Accommodation of Conflicting Public Policies, 64 N.C.L. REv. 219 (1986); Atwood, Issues in Federal-State Relations Under the Federal Arbitration Act, 37 U. FuA. L. RBv. 61 (1985); Hirshman, The Second Arbitration Trilogy: The Federalization of Arbitration Law, 71 VA. L. REv. 1305 (1985).

107 See, e.g., Longshoremen's \& Harbor Workers' Compensation Act, 33 U.S.C. § 921(d) (1982); National Labor Relations Act, 29 U.S.C. \& 160(e) (1982).

${ }^{193}$ See Crowell v. Benson, 285 U.S. 22, 57 (1932) (Congress may not shift the "essential 
Arbitration and agency decisionmaking were understood to be somewhat akin to, but also somehow distinct from, judicial decisionmaking. Today, however, many involved with ADR advocate that its methods be brought into the courthouse ${ }^{198}$ and that judges make ADR their own--either by sponsoring or by running it. ${ }^{200}$ In this respect, ADR (in the form of court-annexed arbitration, judicial settlement conferences, summary jury trials, and mediation) offers not only an alternative to, but often a replacement for, adjudication. ${ }^{201}$

Judges have always engaged in activities other than formal adjudication. ${ }^{202}$ But, over the past decade, there have been important shifts in emphasis, frequency, and visibility of these aspects of the judicial role. Moreover, as judges engage in or supervise the various ADR processes, the line between adjudication and the other activities blurs. As noted above, both legislation and constitutional interpretation have mandated adjudicatory modes for agencies-blurring the line by making agencies behave more like courts. Now the pressure is mounting from the other direction, as efforts are made to convince judges to adopt less adjudicatory behaviors. Because adjudication is, by definition, that which a judge does, the effort to engage judges in alternative dispute resolution must be understood, in part, as an effort to redefine adjudication.

The motivations for advocating ADR to judges are as diverse as its champions. ${ }^{203}$ For those who offer themselves for hire to perform $\mathrm{ADR}$, there are obvious economic incentives. Others seek shelter in $A D R$ as a means of resolving their disputes safe from public scrutiny. ${ }^{204}$ Others simply argue that adjudication is too

attributes of judicial power" to agencies).

109 See E. Lind \& J. Shapard, Evaluation of Court-Annexed Arbitration In Three Federal District CourTs 92-93 (1983); Lambros \& Shunk, supra note 146, at 43; Sander, Varieties of Dispute Processing, 70 F.R.D. 111, 131 (1976).

${ }^{200}$ Cf. FED. R. Crv. P. 16(c)(7) (federal judge may, at pretrial conference, discuss the possibility of the "use of extrajudicial procedures to resolve the dispute").

${ }^{201}$ Some of the "alternatives" of earlier years were also genuine supplements, in that, prior to their enactment, no remedies were available-in court or elsewhere. See Perlin, The German and British Roots of American Workers' Compensation Systems: When is an 'Intentional Act" "Intentional"?, 15 SETON Hall L. Rev. 849, 849 (1985) (workers' compensation evolved in response to early limitations on ability of workers to sue their employers).

202 Scliwartz, supra note 140, at 438-39.

${ }^{203}$ See, e.g., Menkel-Meadow, Toward Another View of Legal Negotiation: The Structure of Problem Solving, 31 UCLA L. REv. 754 (1984); Olson, Dispute Resolution: An Alternative for Large Case Litigation, Limgation, Winter 1980, at 22, 24.

${ }^{204}$ See Green, Private Judging, Trial, Oct. 1985, at 36, 39-40; Note, The California Rent-a-Judge Experiment: Constitutional and Policy Considerations of Pay-As-You-Go Courts, 94 Harv. L. Rev. 1592, 1599-1600 (1981). 
cumbersome, that it costs too much, that it requires too much counter-productive behavior, and that "mini," "summary," or abbreviated proceedings are better. Yet others have serious quality claims to make affirmatively on behalf of ADR. ${ }^{205}$ Some ADR mechanisms are predicated upon the assumption that hitigants, and not their lawyers, are the key actors to be engaged in dispute resolution. In contrast to the Federal Rules, which tacitly posit the lawyer as central, some of the ADR procedures are designed to foster direct participation by litigants. In this respect, some ADR mechanisms do not reject the adversarial mode but only question the faith in the lawyer-chent unit. Yet other ADR procedures confront the assumptions of the desirability of adversarial approaches and seek to develop a range of more cooperative responses beyond those typically employed in and by courts. ${ }^{208}$ Underlying all these diverse views is a sbared aversion to adjudication. ${ }^{207}$

While much of the energy for managerial judging and ADR comes from a desire to produce less expensive outcomes, the two enterprises do share a qualitative theme: both assume that dispositions based upon the consent of the parties are somehow better than tbose achieved by adjudication. ${ }^{208}$ Sometimes "better" simply means cbeaper and quicker. Occasionally, however, "better" is premised upon something more: that consent is preferable to adjudication as a basis for action. Again, this notion is not novel; ${ }^{209}$ consent theories animate much of the political discussion in the

203 See Menkel-Meadow, supra note 203, at 763-64; Menkel-Meadow, Judges and Settlement, TriaL, Oct. 1985, at 24, 27. Some of the ADR hiterature contrasts what it can offer with court-based remedies, which are described as "win/lose" events. See, e.g., MenkelMeadow, supra note 203, at 789-93. I think this view understates the complexity of many decisions reached by courts, in which parties may both win and lose.

${ }^{206}$ See Menkel-Meadow, supra note 203, at 789-93; Menkel-Meadow, supra note 189, at 487.

${ }^{207}$ See Chief Justice Urges Greater Use of Arbitration to Relieve Courts of Litigation Burdens, The ThIrd BRANch, Oct. 1985, at 1, 1 (tort lawsuits divert "people . . . from their normal pursuits and sometimes makes them neurotics").

${ }^{208}$ Compare McThenia \& Shaffer, supra note 7, at 1664 (settlement "exalts" the remedial process and "calls on substantive community values"), and Menkel-Meadow, supra note 203, at 754 ("To sue is human, to settle divine"; quoting sign in U.S. Magistrates Office), with Alschuler, Mediation with a Mugger: Concerning the Shortage of Adjudicative Services and the Need for a Two-Tier Trial System in Civil Cases, HARv. L. REv. (forthcoming) ("Americans . . . settle too many civil cases," and settle them "for the wrong reasons"-inadequate adjudicative services, complex pretrial and trial procedures, substantive uncertainty, judicial pressures, and strategic oppression), and Fiss, Out of Eden, supra note 7, at 1670 ("Chief Justice Burger is not moved by . . . a desire to find new ways to restore or preserve loving relationships, but rather by concerns of efficiency and politics.").

208 For a classic example, see Françors Raberais, Gargantua and Pantagrugl bk. 3, chs. 39-43, at 396-408 (J.M. Cohen transl. 1955). 
United States, and those theories are appropriately mirrored in court processes. But again there has been a shift in emphasis. The perceived desirability of settlement is based not only upon the general "goodness" of consent, but also upon the devaluation of adjudication as it is currently conducted with lawyer-based information generation and presentation. ${ }^{\mathbf{2 1 0}}$

In sum, on both the criminal and the civil sides-and relying upon rules, cases, and informal practices-the judiciary is in the midst of devising or borrowing mechanisms to bypass adjudication. Once dispositions are made, they are difficult to undo. Evidence of this trend appears in a variety of contexts: judicial involvement in settlement in civil cases, efforts to limit discovery rights, the suggestion of precluding appeals-as-of-right, ${ }^{211}$ the growth of waiver doctrines, the increased deference to first-tier decisionmaking. One wonders whether the current limitations on federal judges' participation in plea bargaining will last the decade. ${ }^{212}$

Some of these procedural reforms appear to be advocated and propagated by those whose interests are to be served by a decline in adjudicatory procedure. For example, many defendants (and their attorneys) in products liability and antitrust cases have championed the curtailment of discovery and now seem intrigued by $\mathrm{ADR}$ as a means of protecting themselves from negative publicity and from outcomes they have disliked. ${ }^{213}$ Still, much of the energy comes from judges who are not acting at the beliest of such economic imterests. Ratler, some judges, who are intimately famil-

${ }^{210}$ See Menkel-Meadow, supra note 189, at 504-05 (settlement "offers . . . substantive justice that may be more responsive to the parties' needs than adjudication").

211 See Ninth Circuit Senior Advisory Bd., Recommendation to the Ninth Circuit Judicial Council (June 1985, submitted to the Judicial Council in Jan. 1986) (urging the Council to recommend that the Judicial Conference of the United States study whether the jurisdiction of the courts of appeals should be made discrectionary) (on file with The University of Chicago Law Review); see also Dalton, Taking the Right to Appeal (More or Less) Seriously, 95 Yale L.J. 62, 63 (1985); Resnik, Precluding Appeals, 70 CoRnell L. Rev. 603, 60506 (1985).

212 See Fed. R. Crim. P. 11(e). See generally Alschuler, The Trial Judge's Role in Plea Bargaining (pt. 1), 76 CoLUM. L. REv. 1059, 1061 (1976) (a "bargaining process can operate in a fairer, more straightforward manner when judges do take an active part").

${ }^{21 s}$ See, e.g., Jefferson, Frankly Speaking: A View from the Other Side of the Glass, Products Liability, Commentaky \& Cases 14, 15 (Premiere issue, 1986) (written by Chairman, E.I. du Pont de Nemours \& Co.).

The sudden mcrease in visibility of ADR, which is prompted in part by the interest and funds provided by corporations and insurance companies, might be understood as an example of Marc Galanter's "repeat player" analysis. Those who are repeat players in the litigation world may make strategic moves not only to win a given case but also to structure the rules of procedure to their advantange. Galanter, Why the "Haves" Come Out Ahead: Speculations on the Limits of Legal Change, 9 L. \& Soc'y REv. 95, 97, 100-01 (1974). 
iar with the process, are simply and decidedly unhappy about it. When critics (such as I) propose that managerial judging and ADR methods should be constrained by procedural requirements such as recordkeeping and public access, we are met with sometimes patient," 214 sometimes impatient,"15 explanations that "you simply don't understand: the need is to obtain dispositions and procedural formality will just slow us down." In the nineteen-thirties, leading members of the bench and bar were advocating procedural reforms in which lawyers were assigned a central role to develop information which, in turn, would enable adjudication. Their counterparts today are advocating procedural reforms of a different sort. Today's reformers don't seem to like procedural formality, the centrality of lawyers, or adjudication very much at all.

\section{The Future}

How are we to understand the emerging hostility to adjudication? There are several ways to read this story. First, I may be too quick to find a dechine in faith. Fifty years is but a short span of time in which to assess the longevity of procedural developments. One might read Walters, for exainple, as remarkable because three members of the Supreme Court said for the first time that the Veterans Administration, long exempt from much judicial oversight, ${ }^{216}$ should be required to admit attorneys to its proceedings. Similarly, while Congress has not provided full legal services for the poor, Congress has provided some. The recent diminution in the insis-

214 See Peckham, supra note 175 , at 260-67.

21s See Flanders, supra note 176.

216 See generally Rabin, Preclusion of Judicial Review in the Processing of Claims for Veterans' Benefits: A Preliminary Analysis, 27 Stan. L. Rsv. 905, 905 (1975) ("The Veterans Administration stands in splendid isolation as the single federal administrative agency whose major functions are explicitly insulated from judicial review."). For movement away from that isolation, see Johnson v. Robison, 415 U.S. 361, 373-74 (1974) (constitutional challenge to the VA not barred); Crowne v. Walters, 53 U.S.L.W. 2452-53 (D.D.C. Feb. 26, 1985) (No. 82-0827) (judicial review of claims that VA misinterpreted its own regulations). Similarly, while the Supreme Court has declined to require attorneys for indigent parents in all proceedings to terminate their rights, the Court has required lawyers in some of the cases. See Lassiter v. Dep't of Soc. Serv., 452 U.S. 1, 8 (1981). The Court has also recently reaffirmed the important role counsel plays in criminal cases. See Maine v. Moulton, $106 \mathrm{~S}$. Ct. 477, 484 (1985) (counsel must be provided at all critical times after judicial proceedings are commenced). Moreover, one could understand that some of the statutory, regulatory, and constitutionally-based constramts imposed upon entities hike the United States Parole Commission represent major increases in adjudicatory modes in an arena heretofore unconstrained by such requirements. See 28 C.F.R. \$\$ 2.1-2.63 (1985) (Parole Commission regulations); Curtis, Federal Judicial Power, Parole Guidelines, and Sentence Reform, in 2 Prisonkrs' RighTs SourczBooK 91, 106 (I. Robbins ed. 1980). 
tence on lawyer-based adjudicatory procedure may be only a temporary downward turn. My skepticism of this interpretation is evident, but the perspective of another fifty years will be necessary to know which vantage point was correct.

A second possibility is that the current rhetoric is the translation of the concerns of the nineteen-thirties into contemporary terms. In this view, faith has not failed; it has evolved. In the nineteen-thirties, the rulemakers railed against the technical, "rigid" procedure of their time and sought flexibility by liberal rules of pleading and by discovery (to get to the "truth" quickly). What they wanted-simplicity, decisions on the merits, a reduction of reversals on appeal because of procedural mistakes-is what current commentators want. Only the techniques have changed. Then, the hope was that, once freed from the rigidity of the past, adjudication after adversarial encounters shaped by lawyers would produce just results. Today, the hope is that a diminished role for lawyers, fewer opportunities for adversarial development of information, and minimal judicial decisionmaking will produce just results. Both generations share a hostility towards procedure used as an obstacle to truth. Hence, there is no failure of faith but a new insight into where to place faith-today, in a framework that limits the roles played by lawyers and, to a lesser extent, by judges. Further, while the rulemakers of fifty years ago understood some of the problems of parity and attorney misbehavior but thought that the Rules were not the place in which to respond, we have learned that rules of procedure must be structured with those concerns in mind. One difficulty with this interpretation is that it assumes a deep concern among today's reformers for the quality of outcomes rather than the quantity of outcomes produced-a concern less than dominant in the current debate. ${ }^{217}$

A third way to make sense of the changes in the last fifty years is to see them as part of a broader trend in contemporary political culture. In the nineteen-thirties, the rule drafters seemed to have liad faith not only in lawyer-based adjudicatory procedures but also in lawyer-based reforms in general. These gentlemen spoke about justice, trutll, and the grand accomplishments of the legal profession as if they genuinely believed in them all. The Federal

${ }^{217}$ See Rule 16 Commentary, supra note 188; Landsman, The Decline of the Adversary System: How the Rhetoric of Swift and Certain Justice has Affected Adjudication in American Courts, 29 Bupralo L. Rev. 487, 488 (1980). But see Menkel-Meadow, supra note 189 , at 514 ("I cast my vote for quality"). Of course, we lack measures of quality for the outcomes in adjudication, although we have developed surrogate measures. 
Rules of Civil Procedure were drafted and praised as the New Deal was being put into place. Lawyers were, as Gerald Gawalt has labeled them, the "new high priests,"218 and they carried their faith in their abilities and messages into all areas of government. In the intervening fifty years, many of these beliefs have been shaken. Professionalism holds fewer promises; self-interest is readily evident, and indeterminacy is all too apparent. While faith in religious movements may be on the increase, secular faith in group endeavors to benefit society is in decline in general. Procedure is only one arena in which failing faith is evident. From this vantage point, federal judges and proceduralists simply share in a widespread nihilism.

A fourth possibility is that a decline in the valuation of procedure is based upon a realistic appraisal of its potential. During the nineteen-thirties, some of the rule drafters may have been skeptical about ultimate truth (those were the days, after all, in which legal realism emerged), but they seemed in their public commentary to have faith in relying upon procedures to legitimate outcomes. The belief was that better procedures produced better facts which in turn yielded preferable outcomes. Such a faith was reiterated in the due process revolution of the late sixties and early seventies, as procedure became a major medium for protecting individuals' opportunities to challenge their government. Indeed the due process revolution might be understood as valuing procedure as much as outcomes (and has been criticized for valuing procedure more than outcomes). ${ }^{219}$ During the past fifteen years, procedure has proved to be an insufficient medium by which to express concern about individual dignity. The problems sought to have been resolved through procedural reform persist, and some accuse procedure of masking or worsening the indignities visited upon the citizenry. ${ }^{220}$ The decline in faith in adjudication and some of the open hostility towards the courts are based upon this absence of progress.

A final possibihty is that no one ever cares about adjudicatory procedure per se. It is always a means to an end-a technique for estabhshing another agenda. The "procedure" cases of the

218 The New High Priests, supra note 25, at vii.

210 See, e.g., Simon, Legality, Bureaucracy and Class in the Welfare System, 92 YALE L.J. 1198, 1201-04 (1983).

250 Id. at 1200-22. Simon argues that, in part because of the due process litigation of the last two decades, social workers are permitted less discretion in dealing with those on welfare-a change that has worsened the lives of beneficiaries. 
nineteen-fifties, sixties, and early seventies could all be understood as not really about process but as efforts to use procedure to achieve results the Court believed appropriate. The contemporary "procedure" cases simply exemplify the agenda of a new majority. Similarly, one could understand the rulemaking activities as prompted by goals other than procedural reform. In the nineteenthirties, lawyers and judges saw the possibility of improving their lot by restructuring the ways in which they worked, so they advocated a series of rule reforms which enhanced their professional lives and which advanced the interests of their clients. ${ }^{221}$ Today, a new generation of lawyers and judges struggles to rid itself of the conditions found oppressive. Bored with the tedium of writing, answering, and ruling upon discovery requests, fearful of public criticism of the waste and inefficiencies of their work, lawyers and judges once again propose new reforms to protect self-interest. Lawyers seek new arenas in which to work; now the training sessions encompass information about the role of the lawyer in alternative dispute resolution. Judges, facing an increasingly bureaucratic task, are searching for means by which to rise above that anonymous role. ${ }^{222}$

However one reads the story, we must come to terms with contemporary events; we must rewrite or leave untouched the federal rules of practice and procedure. What then are the options before us? The answers will vary depending upon which of the several readings proposed above is adopted. For example, if one understands the last fifty years as evidencing a continuing commitment to lawyer-based adjudicatory procedure, then all that needs to be done is to try harder to make that vision work. This approach would require several reforms, including substantial funding for those not able to afford to "do battle." Not only would the budget of the judiciary have to be increased, but we would also have to make more money available (whether by constitutional interpretation or by legislative enactment) for criminal defense and for legal services in a variety of contexts. ${ }^{223}$ Competency levels for lawyers

221 See supra note 40 and accompanying text. John Leubsdorf makes a parallel argument for current support by attorneys for statutes mandating court-awarded fees. See Leubsdorf, supra note 129 , at 33 .

${ }^{232}$ See Fiss, The Bureaucratization of the Judiciary, 92 YALE L.J. 1442, 1443 (1983).

22s The current limits on the Legal Services Corporation would have to be reconsidered. See, e.g., 45 C.F.R. $\S 1611.3($ b) (1984) (income not to exceed $125 \%$ of the Federal Poverty Income Guidelines); id. § 1615.2-.3 (legal services may not be rendered to prisoners seeking habeas corpus rehef); id. $\S 1617.3$ (class actions may only be litigated with approval of local office director). 
would have to be established and policed ${ }^{224}$ to ensure that the funding was accomplishing its objectives.

Funding the underequipped or the unequipped would not suffice; we have come to understand that problems in the adversarial model arise not only from an absence of resources but also from an abundance of resources. ${ }^{225}$ Thus, we would have to take the enterprise of regulating litigation-as suggested by some of the 1983 amendments to the Federal Rules-substantially further. We would have to contemplate ceilings as well as floors on expenditures specific to particular kinds of cases. Substantial sophistication would be required. Given the complexity of the task, its expense, and today's anti-regulatory climate, this alternative is unlikely to be popular. ${ }^{228}$

While this first approach may not be feasible, a related version may draw more support. Accepting the absence of major new funds, we might assume that a partially working, lawyer-based adjudicatory process (a "second best" solution) is preferable to other options. For example, while the marketplace for attorney services is complex, government intervention and some private market arrangements (such as the contingency fee) have provided attorneys and resources for some groups of litigants. ${ }^{27}$ A semblance of balance exists, and adjudication can occur in a fraction of the cases filed. Perceiving the sometimes functioning of the adversarial adjudicatory process as a major accomphishment, one might urge minor tinkering but with essential fidelity to the current procedures. The weakness of this response is its failure to address the constant stream of criticism about attorney misbehavior, the sprawling nature of many disputes, and the dissatisfaction of many participants with the current procedures. If I am correct, and faith is failing, constancy to the old order lias a martyr-like quality.

234 See Genego, The Future of Effective Assistance of Counsel: Performance Standards and Competent Representation, 22 AM. CRIM. L. REv. 181, 203-11 (1984).

${ }^{293}$ See, e.g., Berkey Photo, Inc. v. Eastman Kodak Co., 603 F.2d 263, 268 (2d Cir. 1979) (describing extensive pretrial activity), cert. denied, 444 U.S. 1093 (1980); JAMES STEWART, The Partners 327-65 (1983) (describing the Kodak litigation); see also Miller, supra note 129 , at 9 (adversarial efforts to exhaust opponents by a plethora of papers).

${ }^{236}$ See, e.g., Levine, Is Regulation Necessary? California Air Transportation and National Regulatory Policy, 74 YALE L.J. 1416 (1965); Levine, Revisionism Revised? Airline Deregulation and the Public Interest, 44 LAw \& ConTBMP. ProBs. 179 (1981).

${ }_{237}$ Two forms of intervention are currently in use-direct subsidy and fee shifting. The Legal Services Corporation Act, 42 U.S.C. $\$ \S 2996 \mathrm{a}-2996 \mathrm{k}$ (1982), and the Criminal Justice Act, 18 U.S.C. $\$ 3006$ A (1982), are examples of direct subsidies. For a list of federal feeshifting statutes, see Marek v. Chesny, 105 S. Ct. 3012, 3035-39 (1985) (Brennan, J., dissenting). 
If one holds the view that a new faith has evolved over the past half century, another possibility is to embrace a new agenda: develop means to produce inexpensive outcomes in the mass of cases now before the courts. Relying upon Justice Rehnquist's views in the veterans' benefits case, one could champion the dehvery of decisions to vast numbers of persons in an "informal," "nonadversarial" context."228 In such schemes, the government and the applicants are viewed as sharing a unity of interests. The formalities of lawyers, records, and statements of reasons for decisions-understood as constraints upon abuses of power-are not needed. The juvenile court reforms of the early part of this century were founded in part upon such a view, as were reforms of prisons and other institutions. ${ }^{229}$ Some of us read the history of those movements as estabhishing that such faith in those charged with making decisions about others' hives is misplaced. ${ }^{230}$ But other commentators are more sanguine about the ability of judges, other governmental officials, and private decisionmakers to perform their tasks well without formal constraints. Advocates of managerial judging and ADR are among those confident that informal exercises of power can be used wisely as well as effectively. ${ }^{231}$

As the title of this essay indicates, my sense is that faith in adjudication has declined. I am, however, slow to embrace the faith which proponents of managerial judging and ADR urge upon us. My sympathies for and difficulties with both movements are animated by the same concerns. I agree that the procedural format crafted fifty years ago no longer responds adequately to many issues that consume us today: the gross imbalance between litigants in certain kinds of disputes, the inabilities and misbehavior of lawyers and parties in categories of cases, the large number of disputes seeking attention, and the enormous difficulties, in some cases, in

228 Walters v. National Ass'n of Radiation Survivors, 105 S. Ct. 3180, 3196 (1985).

${ }^{228}$ Elleen Ryerson, The Best-Laid Plans: America's Juvenile Court Experment 35 56 (1978); Estelle Freedman, Their Sisters' Keepers: Women's Prison Reform 109-25 (1981).

${ }^{230}$ See, e.g., W. Gaylin, I. Glasser, S. Marcus \& D. Rothman, Doing Good: The Limits OF BENEVOLENCE 105-24 (1976).

${ }^{231}$ In managerial judging, for example, the assumption is that judicial intervention promotes quick outcomes and that formality inhibits the useful role managerial judges can play. Some have linked the emergence of managerial approaches to the acceptance of continental approaches to procedure. See, e.g., Langbein, supra note 44, at 858-63; Alschuler, supra note 208, at 44-57. According to Professor Langbein, German judges are substantially constrained by their training and selection and by the prospect of de novo appellate review. But Langbein nonetheless advocates that the United States adopt the German model despite the absence of such constraints in this system. Langbein, supra note 44 , at 848-57. 
claiming that the outcomes achieved resemble "truth" or any approximation of it. However, the new replacements seem to me to share some of the same failings. Indeed, as I look at the supplements, like managerial judging and much of the ADR menu, I find them unresponsive to the very concerns that prompt some of their advocates to commend them.

If we all agree that imbalance is a problem in many cases, that attorneys or parties are exploitative or inept, that lots of cases are demanding attention and that legitimate outcomes are difficult to generate, then how do quick dispositions help-other than by obfuscating the problems we have found? Are settlements achieved under conditions of imbalance, lawyer ineptitude, indeterminacy, and judicial coercion any better than adjudication reached under similarly troubhing conditions? Can the label "consent" solve any more problems than does the label "judgment"? 232

Especially troubling for me is the fact that these alternatives empower decisionmakers without providing sufficient justification of why they deserve expanded authority. I am sympathetic to the needs to improve our responses to disputes. I have no romantic or nostalgic attachment to any particular procedural form. But I do hold a strong commitment to the need for constraint of all actors, judges and other decisionmakers, parties, and lawyers, and I am uneasy about approaches which shde over the problem of constraint. Adjudication is far from perfect. But what it offers is decisionmaking by government-empowered individuals who have some accountability both to the immediate recipients of the decisions and to the public at large. Our current definitions of adjudication include a packet of attributes which I continue to respect. Judges must work within reach of the pubhic; some of the processes occur literally in view of the public, and most decisions made in private are reported to the public. ${ }^{23 s}$ When juries decide, no reasons must

232 In this sense, I am less sanguine than Owen Fiss about the ability of adjudication to right the balance. See Fiss, Against Settlement, supra note 7, at 1076-78.

${ }^{23 s}$ On the criminal side, the public's right of access to trial and trial-like proceedings has been established. See Waller v. Georgia, 104 S. Ct. 2210, 2216 (1984) (sixth amendment rights of accused); Richmond Newspapers, Inc. v. Virginia, 448 U.S. 555, 580 (1980) (first amendment rights of audience). The public's riglits of access to civil proceedings and to pretrial activities are less clearly established. See Seattle Times Co. v. Rhimehart, 104 S. Ct. 2199, 2206-07 (1984) (hitigant has no "unrestrained right to disseininate information . . . obtained through pretrial discovery"); In re Reporters' Committee for Freedom of the Press, 773 F.2d 1325, 1338-39 (D.C. Cir. 1985) (because lawsuit between corporate officers of Mobil Oil Corporation and the Washington Post is a "private" case, the public interest in its outcome is reduced and the right of access to papers filed in the case is limited). But cf. In re San Juen Star Co., 662 F.2d 108, 118 (1st Cir. 1980) (implying that first amendment may 
be given; the community's judgment, as expressed by this ad hoc political institution, requires no explanation. But when judges, who regularly hold the government's power of decision, render judgment, articulated explanation is demanded. In many instances, unhappy litigants can voice their displeasure by invoking appellate review, and judicial decisionmaking is bounded by a series of norms about acceptable behavior. These safeguards are far from complete; poor decisions continue to be rendered and to survive, and judges have much unreviewable power. But the adjudicatory mode offers some theory of its own limits, of what counts as permissible and impermissible adjudication. The "alternatives" to it liave yet to articulate how we iniglit assess the legitimacy of the outcomes achieved. Speed and superficial lack of expense are, in and of themselves, incomplete answers.

The lessons of the last fifty years are that unbounded faitl is not enough, that we need to articulate the goals we hope to accomplish by structuring systems for the processing of disputes, and then to pay careful attention to the implementation of those goals. Because I still have faith that procedure lias dignitary functions, ${ }^{234}$ and because I lack utter faith in the unbounded and disinterested wisdom of government and of powerful lawyers and litigants, I am unwilling to turn over the task of procedural modeling to those who evidence blind faitl in alternatives to adjudication or who evidence no faith at all.

\section{The Federal Rules}

Witl the lessons from the past fifty years in mind, I address the more immediate task: low to approacl the Federal Rules of Civil Procedure, fifty years later. I think we need to acknowledge that frank reconsideration of the Rules has begun, sub silentio, by the many clianges advocated, some of which (such as managerial judging and attorney sanctions) are already in place. But to speak openly about a comprehensive review is not to urge abandonment of all (or many) of the clioices made fifty years ago; rather, these choices must be considered in light of the developments of the last five decades. In sliort, I hope that we celebrate the fiftietl anniversary of the Federal Rules of Civil Procedure with sympatlietic admiration; we know not wliat events will make our own work timebound. 
Given the problems of contemporary litigation, the Rules need reworking in several respects. First, the trans-substantive premise of the Rules has proved unworkable. We must face that, whatever the horrors of forms of action, we need to determine what subsets of cases require special kinds of rules, and write rules for those kinds of cases. Thus, a plea for contextualism.

One risk in this approach must be flagged at the outset. It is easy, as the papers in this symposium illustrate, ${ }^{235}$ to revamp the Rules solely to meet the problems created by high visibility lawsuits-the toxic tort and other mega-cases that have stimulated much of the current commentary on the federal courts. Given the membership of the Advisory Committee and the work experiences of many who comment upon procedure, the so-called "ordinary case,"236 in which the Court and the parties invest few or no resources, is often forgotten. ${ }^{237}$ It is important that we keep im mind that more than 40 percent of the federal docket ends without any court action whatsoever ${ }^{238}$ and that 50 percent of federal cases are estimated to be withdrawn or settled without any discovery. ${ }^{239}$ In our efforts to curb abuses and to police adversarial excesses and adjudicatory weaknesses in the "Big Case," we must be careful not to impose inappropriate burdens on the so-called "ordinary case."

Let me provide two examples. Some local districts, distressed about attorneys' behavior in discovery, now require attorneys who request court assistance in obtaining discovery to document their efforts to confer witl opposing counsel. ${ }^{240}$ This documentation requirement may make sense in the context of a case laden witl discovery problems. Further, a local rule counseling cooperation may be good advice in all cases. The documentation requirement, however, may so increase the costs of discovery that a party seeking court aid on a small matter may be deterred. Similarly, Rule 16's requirement that the court issue a pretrial schedule within 120 days of the filing of a complaint may be appropriate for cases with a foreseeable activity-filled pretrial period. But for the more than forty percent of cases that terminate without any court action, the

${ }^{28 s}$ E.g., Brazil, supra note 145; Schuck, supra note 9.

236 See Trubek et al., supra note 114, at 83-84, 89-90.

${ }^{287}$ See Subrin, The Law and the Rules, N.Y. Times, Nov. 10, 1979, at p. 23, col. 4.

28* 1984 Administrative Office Report, supra note 6, at 280 (47\%). Of course, some of these are the contemporary "hip pocket" cases-the parties hope never to higate, and use the filing as a mechanism to obtain a settlement.

230 P. Connolly, E. Hollzman \& M. Kulman, supra note 114, at 28 (based upon discovery requests recorded with the court).

140 See, e.g., CaL. Locar RuLes Cods $\$ \S 7.15 .1-7.15 .2$, at 750 (West 1985) (C.D. Cal.). 
time spent creating a pretrial schedule is wasted. At first glance, Rule 16 seems to acknowledge and solve this problem: the Advisory Committee notes provide that district courts may, by local order, exempt categories of cases from the pretrial schedule requirement. Yet the notes suggest that such exceptions be made for cases involving habeas corpus, forfeiture, and social security disability issues $^{241}$ - cases hitigated by the very individuals particularly in need of judicial assistance to bridge adversarial imbalances. Rather than showing sensitivity to the problems raised by different kinds of cases, the current version of Rule 16 exemphifies the need for thoughtful contextual analysis.

Moving to a process point, the trans-substantive Rules could be contextualized in one of two fashions-through ad hoc decisionmaking by individual judges or districts, or through comprehensive rulemaking. My own views on this issue are well-known; I am deeply skeptical of the capacity of individual judges to craft rules on a case-by-case basis. ${ }^{242}$ Federal judges tell us repeatedly that they are overwhelmed by their caseloads. I do not believe that these judges can perform tlieir adjudicatory tasks and still have sufficient time to ascertain whicl mode of procedure is best suited to eacl individual case. ${ }^{243}$ Moreover, I liave substantial reservations about the propriety of such an ad hoc judicial enterprise. Deciding low to mold procedures to a given case may well involve a judge so deeply in managerial and adversarial events that it undermines the ability of the judge to adjudicate-should that become necessary. ${ }^{244}$ Therefore, I suggest that federal judges participate in the effort to review the Rules, ratlier than in the design of specific procedures for eacli case. ${ }^{245}$

Third, the Rules must come to grips witl tlie question of court regulation of attorneys. We can no longer leave attorney behavior

${ }^{241}$ Fed. R. Civ. P. 16(b), 1983 Advisory Committee Note.

212 See Resnik, supra note 17, at 417-31.

24s According to Hon. Gerald L. Goettel of the United States District Court for the Southern District of New York, judges on that court have, at most, one half an hour of time to devote to the pretrial process of the cases on their dockets. Letter from Hon. Gerald L. Goettel (May 13, 1986) (on file with The University of Chicago Law Review).

${ }^{244}$ In recognition of this problem, some federal districts have local rules which, absent the parties' consent, prohibit judges who participate in settlement negotiations from presiding at trial. See, e.g., CAL. Civil Rules Code \& 240-1, at 685 (West 1985) (N.D. Cal.). The Chief Judge of the Northern District of California suggests that settlement negotiations be referred to a different judge or to a magistrate. See Peckham, supra note 156, at 264; see also Schuck, supra note 9, at 364 (discussing the option).

${ }^{245}$ Of course, the apphication of rules involves judicial discretion; some judicial tailoring of rules to fit the needs of specific cases is inevitable and appropriate. What must be avoided is unrestrained discretion. 
to ethical codes and assume the feasibility of procedural rules that ignore lawyers' practices. One interesting effort to draft standards of behavior for lawyers and incorporate them into court rules has been made by a group spearheaded by Jack Weinstein, Chief Judge of the Eastern District of New York. He recently adopted a standing order, drafted by a group of lawyers, that provides detailed explanations of appropriate discovery practice. ${ }^{246}$ Rules of procedure must detail what attorney conduct is to be countenanced and what is to be penalized. ${ }^{247}$

Finally, we must decide what the Rules should say about settlement-and specifically, about the judge's role in shaping settlements. Some may think that proposing rulemaking about settlement is odd. Settlement is, after all, an agreement between the parties to conclude their dispute without adjudication, and rulemaking implies the need to regulate some adjudicatory function of judges. But both the Rules and practice have drawn judges into two phases of the settlement process: negotiating settlements and approving settlements. The task of approving settlements came first; the 1938 Rules required that class actions would not be withdrawn or compromised without court approval. The 1983 amendments have given judges a role in designing settlements; rule 16 now provides that settlement and the "use of extrajudicial procedures" ( $\mathrm{a} / \mathrm{k} / \mathrm{a}$ ADR) are two of the "subjects to be discussed at pretrial conferences."248 That amendment confirmed a role that many judges had already assumed. Further, the debate of the last few years about enlarging the scope of rule 68 is, at heart, a debate about how much power to accord judges in promoting settlements. One proposed revision of rule 68 would have added a third settlement-related task to judges' platters-sanctioning parties who "unreasonably" refused to settle. ${ }^{249}$ One need not be in favor of such an expansion of the judicial role to understand the need for rulemaking in this area; problems appear under the current Rules. As the Agent Orange example demonstrates, judges currently participate in the structure of a settlement and then sit in judgment

216 See supra note 148.

217 I do not underestimate the difficulties of such an enterprise. The implementation of Judge Weinstein's rules is proving to be difficult, and one of the major problems is the frequent turnover of lawyer personnel (in large law firms and in government) during the course of a lawsuit. Conversations with Prof. Margaret Berger, Principal Investigator, Brookdyn Law School Project on Discovery (Oct. 1985 \& Apr. 1986).

${ }^{216}$ Fed. R. Crv. P. 16(c).

249 See Marek v. Chesny, 105 S. Ct. 3012, 3033-34 \& nn.56-58 (Brennan, J., dissenting). 
to approve the "fairness" of the bargain made. ${ }^{250}$ Finally, the eruption of interest in settlement stands alongside the many federal statutes which provide incentives for successful hitigants; we encourage filings of lawsuits yet discourage their adjudication.

In what capacity do judges act when raising the issue of settlement, when directing parties to engage in ADR, or when approving the compromises reached? Are judges who require settlement negotiations implementing a societal decision that we no longer offer trial-as-of-right to any litigant who so desires and who has the resources and stamina to insist upon one? Or does judicial promotion of settlement signal an all-encompassing preference for settlement over adjudication, wherever and whenever possible? Are there categories of cases in which such a preference is inappropriate? ${ }^{251}$

We must consider not only the legitimacy of the pursuit of settlement but the more specific question of the sources and scope of judicial authority over that activity. At the doctrinal level, it is not clear in what ambit a federal judge works when involved in settlement. Three members of the Supreme Court have suggested that, once the parties have agreed to withdraw or settle a lawsuit, no "case or controversy" exists, and judges therefore lack the power to insist upon any particular agreement. ${ }^{252}$ Under this view, legislation or rules that grant judges authority to restructure elements of settlements are unconstitutional, and judges cannot insist upon provisions to protect the parties or the pubhc. Recently, a majority of the Court endorsed a weaker version of a doctrinal limitation on judicial involvement in settlement. While assuming that judges have the power to "approve or reject a settlement negotiated by the parties," the Court insisted that judges lack authority to "require the parties to accept a settlement to which they had not agreed." 253 By implication, judges may also have no role in ne-

\footnotetext{
${ }^{230}$ See, e.g., In re "Agent Orange" Product Liability Litigation, 611 F. Supp. 1396, 1410 (E.D.N.Y. 1985) (settlement was "fair, reasonable and adequate").

2s1 Proposed drafts for revision of Rule 68 have included suggestions that its sanctions not be applied in cases involving class actions or those seeking imjunctive relief. Proposed Court Rules, supra note 152, at 432-44. Opponents of the proposal, myself among them, have argued that the exemptions stated are too narrow; in our view, sanctions for insisting upon trials are inappropriate in any case in which Congress has created statutory incentives to litigate. USC Law Professors' Testimony, supra note 172, at 7-8; see also Fiss, Against Settlement, supra note 7, at 1085-90 (objecting particularly to settlements in certain kinds of cases, but also rejecting a "two track" system in which some cases are slated for settlements, others for adjudication).

${ }^{282}$ Maryland v. United States, 460 U.S. 1001, 1004-06 (1983) (Rehnquist, J., joined by Burger, C.J., and White, J., dissenting).

${ }^{283}$ Evans v. Jeff D., 106 S. Ct. 1531, 1537 (1986).
} 
gotiating (rather than ordering) terms of settlements; either the parties have a "case" for which adjudication is required, or the parties make private compromises to avoid adjudication.

The Federal Rules-both criminal and civil-contain echoes of the ambiguity about the judicial role in settlement. The Federal Rules of Criminal Procedure expressly prohibit a federal judge from "participat[ing] in any [settlement] discussions," although the prosecution and defense can negotiate a settlement which includes a specific sentence and the judge may accept or reject that agreement. ${ }^{254}$ In contrast, the Civil Rules permit judges to discuss settlement at pretrial conferences. ${ }^{255}$ Both sets of Rules authorize judges to disapprove of some settlements. In criminal cases, the government may not withdraw indictments without court permission; however, the rule is silent on when "leave of court" should be denied. ${ }^{258}$ Plea bargains are also not final absent court inquiry into defendants' understandings of the options available. ${ }^{257}$ In civil cases, class actions and receiverships may not be withdrawn or compromised without court approval, but again no test for that approval is provided. ${ }^{258}$ The justification for court approval in both criminal cases and class actions is the saine: the judicial role is to protect third parties (in the criminal context, the public, and in the class action context, the physically absent members of the class) from decisions made by potentially disloyal representatives. ${ }^{259}$ In other words, we explicitly question the adequacy of the "consent" to judgment. However, what we do with our qualms is less clear; short of adjudication, judges have difficulty assessing the quality and fairness of the agreements reached. Further, compelhing individuals to litigate is problematic; the very rare refusal of a district court to accept a prosecution's motion to dismiss an indictment is testimony to those difficulties. ${ }^{260}$ Finally, aside from the criminal area, class actions and receiverships, and a few special

${ }^{254}$ FED. R. CRIM. P. 11(e)(2).

${ }^{285}$ FED. R. Cr. P. 16(a)(5).

${ }^{288}$ Judicial supervision of such decisions has in fact been minimal. See United States v. Cowan, 524 F.2d 504, 514-15 (5th Cir. 1975), cert. denied, 425 U.S. 971 (1976).

${ }^{287}$ FED. R. CRIM. P. 11(c).

246 FED. R. CIv. P. 23(e), 66.

2so In addition, in the criminal context, the court's supervision is intended to protect the defendant from poor counsel or prosecutorial overreaching and to protect the conviction, once obtained, from collateral attack.

${ }^{200}$ E.g., United States v. Cowan, 524 F.2d 504, 512 (5th Cir. 1975) (" Few subjects are less adapted to judicial review than the exercise by the Executive of his discretion in deciding when and whether to institute criminal proceedings" ") (quoting Newman v. United States, 382 F.2d 479, 480 (D.C. Cir. 1967)). 
statutory schemes, ${ }^{261}$ the Federal Rules give judges no official role in approving settlements. In the bulk of civil higation, the parties' decisions to settle are not subjected to review. ${ }^{\mathbf{2} 2}$

It is not only the potential absence of judicial power over settlement that is problematic; many fear that during settlement negotiations, judges may have too much authority. The literature on judicial settlement activities documents the subtle and not so subtle pressures asserted by judges when discussing settlement. ${ }^{203}$ Some judicial "suggestions" are understood as more than that-as implicit comments that hitigants who insist upon a trial are acting inappropriately. Again, we are learning that "consent" to judgment may not, in and of itself, be a sufficient guarantee of quality, fairness, or litigant satisfaction.

What should the Rules say about the problem of settlement? Should doctrinal hesitations and concerns for abuses of power lead to the view that judges should only be engaged in adjudication and have nothing to say about resolutions arrived at without adjudication? Should our sensitivity to problems of parity and attorney misbehavior lead us to elaborate upon the class action/criminal rules, to see the judge as protector of both the parties and the public in all cases, and to mandate an active role for the judge im commending specific compromises and disapproving others? If we adopt this approach, how might a judge determine the propriety of a given compromise-without some kind of factfinding process? The cases dealing with class action settlements struggle with this issue, as the courts have developed criteria (the merits of the offer, the likelihood of success, the compromises made by both sides) while cautioning against too much judicial second-guessing or too much adjudication. ${ }^{264}$ On the criminal side, judges have noted the role displacement and intrinsic difficulties of declining to approve

${ }^{201}$ See, e.g., Tunney Act, 15 U.S.C. $\$ \S 16(\mathrm{~b})$-(h) (1982) (antitrust actions initiated by the government cannot be compromised without court inquiry into whether the settlement is "in the public interest").

${ }^{202}$ See FED. R. Crv. P. 41 (voluntary dismissals by stipulation of the parties).

${ }^{203}$ See, e.g., Manual for Complex Litigation, Second § 23.11 (1985) (warning judges not to permit their involveinent in settlement negotiations to undermine the perception of judicial fairness); see also Kothe v. Smith, 771 F.2d 667, 670 (2d Cir. 1985) (holding that a judge impermissibly imposed sanctions when litigants refused to settle for the amounts suggested by the judge); D. Provine, supra note 191, at 30-35.

264 See, e.g., Manual por Complex Litigation, Second $\$ 30.41$ (1985); Armstrong v. Board of School Directors, 616 F.2d 305 (7th Cir. 1980). See also several of the cases constituting In re "Agent Orange" Product Liability Litigation: 611 F. Supp. 1296 (E.D.N.Y. 1985); 611 F. Supp. 1396 (E.D.N.Y. 1985); 611 F. Supp. 1452 (E.D.N.Y. 1985); 618 F. Supp. 623 (E.D.N.Y. 1985). 
compromises to withdraw prosecutions, while finding it somewhat easier to articulate criteria upon which to approve a plea bargain. $^{285}$ In short, developing norms by which to measure settlements is difficult, ${ }^{288}$ for without adjudication, how can a judge determine what results are appropriate, what compromises are fair, or what amount of damages should be awarded? Can we develop some process in between settlement and adjudication and describe the appropriate arena within it for judges? Or would (and does) the involvement of judges in anything less than adjudication diminish the legitimacy of adjudication and reduce the utility of settlement? ${ }^{267}$

At one level, alternative dispute resolution offers some escape from these difficulties. Instead of employing judges to bring about resolutions without adjudication, use "alternatives"-magistrates, special masters, summary jury trials, mini-trials, court-annexed arbitration. But upon reflection, some of the problems associated with judge-sponsored settlements arise within the ADR context as well. If, without adjudication, judges lack adequate information upon which to determine a proper outcome, why should we assume that judicial surrogates can do any better? If consents to entry of judgment are entered by disloyal representatives or because of coercion, how does ADR limit such abuses?

One of the answers to the question may well be that it depends upon the form of ADR employed. There is a tendency (evidenced in this essay and elsewhere) to lump all ADR processes together, but perhaps the time has come to draw distinctions among them. For example, a summary jury trial employs citizens to listen to an abbreviated account of the events at issue and then to advise the parties about the jurors' views of the respective rights and obligations; the case is "tried" in pubhic and members of the pubhic issue a nonbinding judgment. In contrast, court-employed mediators often work in private, sometimes engaging in shuttle diplomacy to convince parties to settle. Because, as described above, I believe that one of the saving graces of adjudication is its "pubhic

${ }^{265}$ The question of whether to approve a plea is not prohlem-free. See North Carolina v. Alford, 400 U.S. 25, 31-39 (1970) (accepting defendant's decision to plead guilty even though he maintained his innocence).

286 See generally Luban, Bargaining and Compromise: Recent Work on Negotiation and Informal Justice, 14 PHIL. \& PUB. Arr. 397 (1985) (problems exist even without third party involvement).

287 For discussion of how judicial involvement in settlement reduces the legitimacy of adjudication, see Sarokin, Justice Rushed is Justice Ruined, 38 RUTGERs L. REv. (forthcoming) (on file with The University of Chicago Law Review). 
dimension"- the accountability and education which flow from its public, visible nature ${ }^{268}$-I have more qualms about mediators than I do about summary jury trials. (The privacy in which managerial judges work distresses me for similar reasons.) If we employ mediators in our publicly-financed system of dispute resolution, how are we to know what they do? whether we share the norms they articulate or the values they convey as they attempt to settle disputes? ${ }^{269}$ whether they attempt coercion as a form of mediation?

Underlying the question of rulemaking about settlement (whether by judges or through surrogates) is a question of faith. Implicit in the praise of abbreviated processes, such as informal settlement conferences and summary jury trials, is the assumption that the quantum of information produced by adjudication is unnecessary - that outcomes every bit as good can be produced with less data, less formality, and fewer constraints. Implicit in claims for adjudication are behefs that disputes are often complex and subtle, that formality empowers, and that those with power must be constrained. Before we write rules about settlement, we need to choose one of these views or identify the cases in which to vary our views. We need further to determine whether we should conserve and confine judges to their speciality, adjudication, ${ }^{270}$ or whether we should assign them the additional task of settlement. If we choose a strong settlement role, we must determine whether we can cabin that activity from adjudication and how we can legitimate judicial exercises of power in that arena. Reliance upon some of the procedures associated with adjudication-visible decisionmaking, the creation of records, pubhic scrutiny and participation, and appellate review-is one way in which to constrain that power, but if we add all those procedures to judicial settlement or to an ADR mechanism, have we done anything other than reinvent the wheel? ${ }^{271}$ The problem of settlement raises fundamental issues about the reach of courts' authority. It is tempting to want to ignore these problems, to pass lightly over the conceptual difficulties,

${ }^{288}$ See Resnik, The Public Dimension (forthcoming) (on file witl the author).

${ }^{268}$ For evaluation of the norms employed by mediators in Germany, see Plett, Mediation and Settlement of Building Construction Disputes: The Case of the "Bau-Schlichtungsstelle" in Frankfurt, West Germany 32-36 (Mar. 1986) (Institute for Legal Studies, University of Wisconsin at Madison, Dispute Processing Research Program, Working Papers Series 7).

${ }^{270}$ See Resnik, supra note 17, at 430-45.

${ }^{271}$ See generally Note, The Dilemma of Regulating Mediation, 22 Hous. L. REv. 841 (1985). 
and to amend rules without facing these questions. But that work must be done, and, in light of its scope, it should not be left to the Advisory Committee alone.

These suggestions do not by any means answer all the problems. For example, what should be done about the sprawling definition of a "case" that permits the events involving Agent Orange to bear that title? When the number of actors and of events becomes so great, the ability of adjudication or settlement to offer acceptable outcomes diminishes. How can any judge, jury, ADR specialist, or expert digest the mass of information needed for deliberative decisionmaking? At such moments, should we abandon our traditional approaches and delight in innovation? Much of the commentary about Agent Orange has welcomed such an approach. ${ }^{272}$ But what about the precedent-a judge negotiating the settlement and then finding it fair? Can we have that model for some cases, such as the extraordinary events labeled Agent Orange, but find it impermissible in other settings? Or, will judges, enamored with the import and seeming utility of their innovations, be content to provide ordinary (sometimes tedious and certainly rarely glamorous) adjudication for most of their caseload? Will the innovations always, in practice, find their way into all parts of the docket?

\section{Conclusion}

As we sit in contemplation of the enormously powerful work of the drafters of the Federal Rules of Civil Procedure, we must be careful and thoughtful in our examination of the decisions made fifty years ago. We must understand that conversations about procedure are often used as vehicles for many other conversations that are difficult to have in a straightforward manner. Proposals for "tort reform" that include caps on hability emanate from those who have to pay damage awards, as well as from disinterested social scientists, concerned about the impact of liability rules and the utility of rehance upon tort higation for risk-spreading and for deterrence. ${ }^{273}$ Desires to abohish appeal-as-of-right come not only

${ }^{272}$ See Blumenthal, How U.S. Judge Helped Shape Agent Orange Pact, N.Y. Times, May 11, 1984, § 1 at 1, col. 2 (one lawyer said, "This was Judge Weinstein's finest hour").

27s The Reagan Administration has proposed federal "reform" legislation in the areas of products liability, government contractor hability, and federal tort liability, all of which aim to limit liability. Product Liability Reform Act of 1986 (on file with The University of Chicago Law Review); Government Contractor Liability Reform Act of 1986, S. 2441, 99th Cong., 2d Sess., 132 Cong. Rec. S5814-15 (1986); Federal Tort Claims Reform Act of 1986, S. 2440, 99th Cong., 2d Sess., 132 Conc. RBc. S5812-13 (1986). Two of these proposed bills 
from those interested in decreasing litigation costs but also from those who wish to give greater power to first-tier decisionmakers and to restrict individuals' abilities to challenge judicial wrongdoing. In short, some of the current vogue for complaining about overuse of the courts and of procedural excesses masks an important, value-laden debate about individual rights and the role of the judiciary in this society. In the current surge of concern about procedural innovation, we must sort out which suggestions are put forth in an effort to limit judicial power and which are made in an effort to enhance the judicial function.

Repeatedly these days, prominent jurists (including members of the Supreme Court) say that litigation and lawyers are bad. These judges provide those hostile to federal rights with a powerful rhetoric. I do not find it at all surprising that judges should rail against caseloads, lawyers, and litigants. From the judicial vantage point, there must appear a never ending stream of cases, of people, of problems, of attorney magnification of minor misdeeds. The yearning for "simple, nonadversarial" resolutions is understandable. Judges have no respites, no sabbaticals, no large salaries. The temptation for judges to wish away all the cases, to advocate higher access fees, fewer appeals, less involvement in adversarial encounters, and the abandonment of adjudication, must be enormous. I urge that we resist the effort to translate judicial exhaustion into rules or practices that devalue adjudication but offer no constrained decisionmaking procedure to take its place.

I have painted a story of fifty years with a broad brush. I have oversimphified and overgeneralized. Counter-examples abound, contrary trends can be divined, and the world is far more complicated than this essay suggests. Granting all that, we must explore the value choices of the nineteen-thirties and of today to determine what kind of procedure to provide those who seek judicial attention. As we contemplate revisions of the Federal Rules, we must seek to preserve many of their accomphishments, including ready access to the judicial apparatus.

also announce it to be the "policy of the United States to encourage" alternative dispute resolution. Product Liability Reform Act of 1986, § 11; Government Contractor Liability Reform Act of 1986, § 11. 

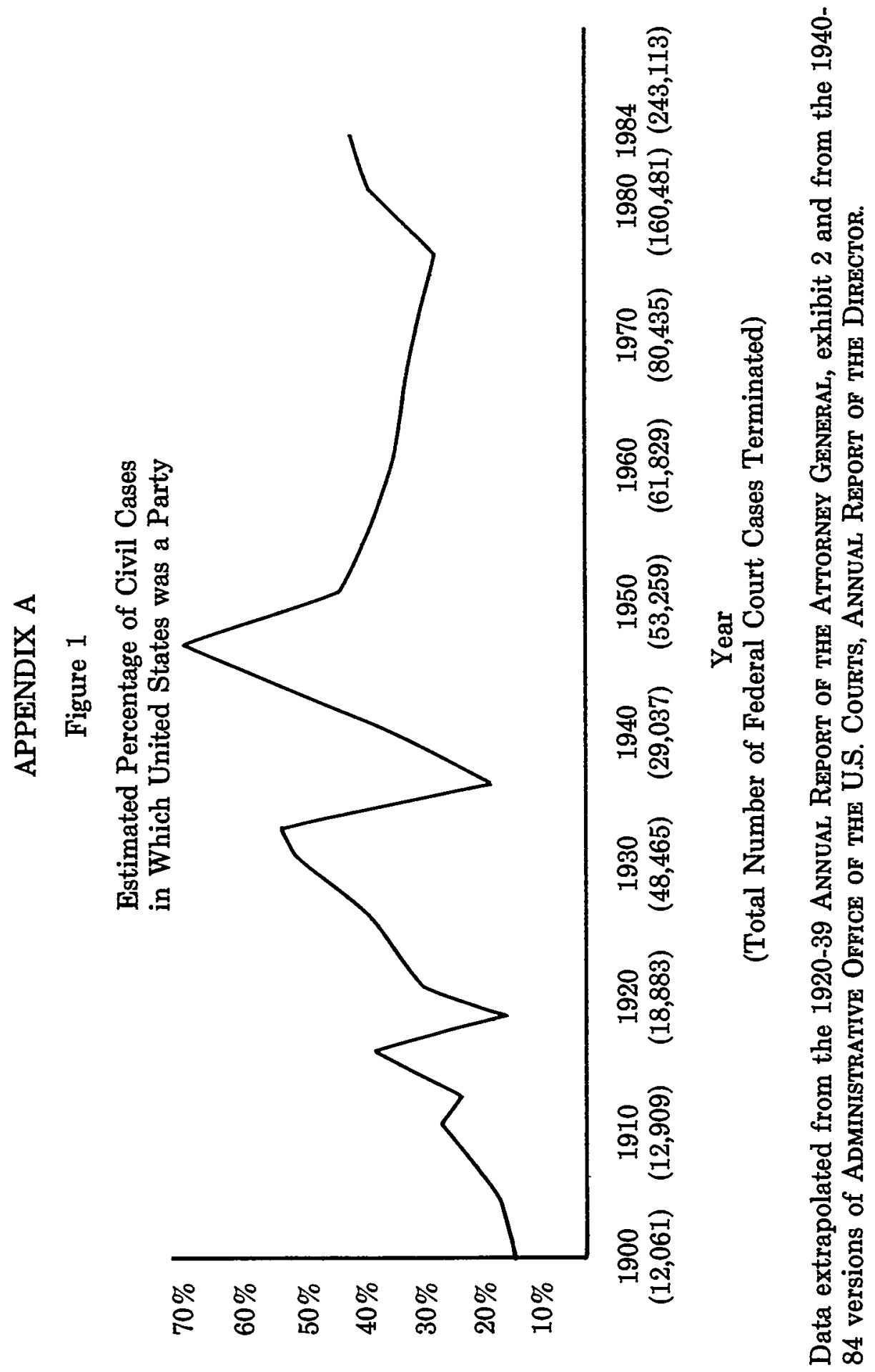
APPENDIX B

\section{Table 1}

ESTIMATED NUMBER OF COMPLETED CIVIL TRIALS

\begin{tabular}{l|l|l} 
Year Total No. Civil & Actual No. Civil & Percentage of Civil
\end{tabular}

\begin{tabular}{c|c|c|c} 
& Cases Terminated & Trials Completed & Trials Completed \\
\hline 1945 & 52,300 & 2,835 & $5.4 \%$
\end{tabular}

1946

61,000

1947

54,515

1948

48,791

48,396

53,259

1950

1951

52,119

1952

53,150

1953

57,490

1954

57,903

1955

1956

58,974

67,700

63,568

1958

61,285

62,172

61,829

1960

1961

1962

1963

1964

1965

1966

55,416

57,996

3,617

5,040

4,586

4,913

4,979

5,051

4,711

4,900

6,943

7,036

7,380

6,892

7,062

6,908

6,488

6,156

n/a*

$\mathrm{n} / \mathrm{a}$

$\mathrm{n} / \mathrm{a}$

63,954

65,478

7,613

7,783

$5.9 \%$

66,184

1967

70,172

68,873

8,095

8,688

8,834

9,449

80,435

86,563

10,093

95,181

10,962

98,259

97,633

10,896

10,972

11,603

11,656

11,604

11,389

11,655

12,951

14,398

14,433

14,391

14,374

$9.2 \%$

9.3\%

$10.1 \%$

$9.3 \%$

$9.7 \%$

$8.9 \%$

$8.5 \%$

$12.0 \%$

$11.9 \%$

$10.9 \%$

$10.8 \%$

$11.5 \%$

$11.1 \%$

$10.5 \%$

$11.1 \%$

$\mathrm{n} / \mathrm{a}$

n/a

$\mathrm{n} / \mathrm{a}$

$11.6 \%$

$11.7 \%$

$11.5 \%$

$12.6 \%$

$12.0 \%$

$11.7 \%$

$11.6 \%$

$11.5 \%$

$11.0 \%$

$11.2 \%$

$11.0 \%$

$10.6 \%$

$9.9 \%$

$9.0 \%$

$8.1 \%$

$8.0 \%$

$8.0 \%$

$7.6 \%$

$6.7 \%$

$5.9 \%$

Data extrapolated from the 1945-84 Administrative Orfice of the U.S. CourTs, ANnual Reports op THe Director, Tales C1 and C8.

*Tables not publisbed for 1962-64. Conversation with James McCafferty, Statistical ADalysis and Reports Division, Administrative Office of United States Courts, May 16th 1986. 


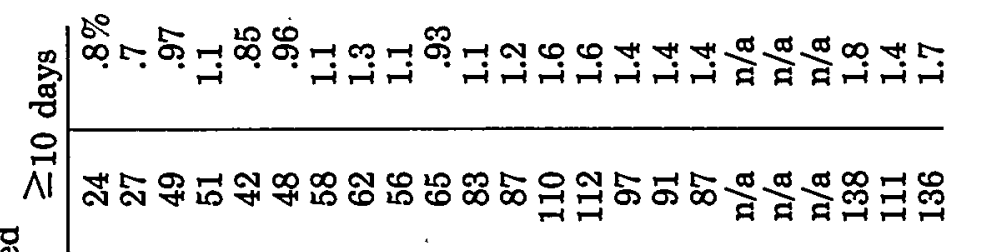

要

兽

す

总

\%

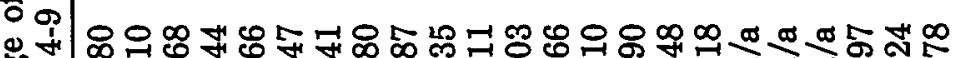

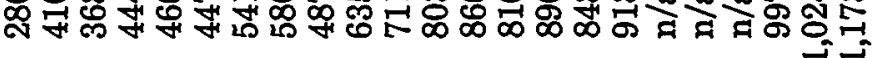

约

ㅇ $\quad$ ம

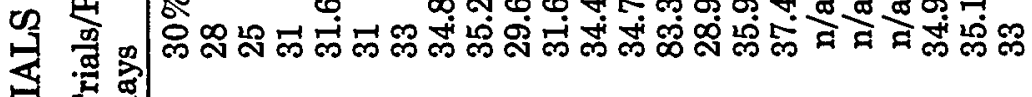
霍

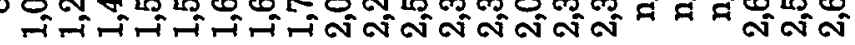
4 운

s9

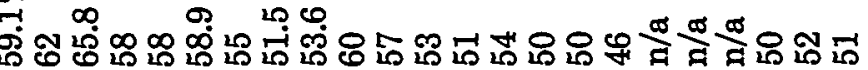

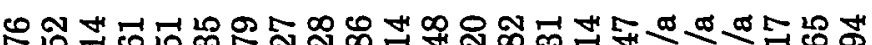
厄,

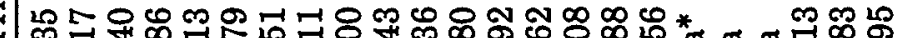

$\infty$ b 잉

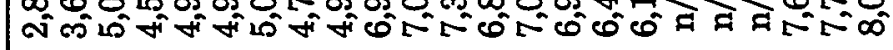
$\circ$ نे z

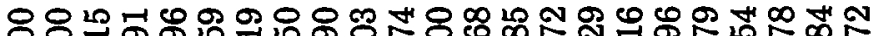

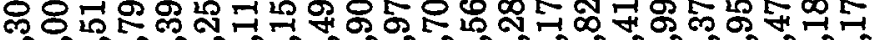
หิ 
